\title{
The Origin and Development of the Central European Man-made Landscape, Habitat and Species Diversity as Affected by Climate and its Changes - a Review
}

\author{
Peter Poschlod ${ }^{\mathrm{a}}$ \\ ${ }^{a}$ Chair of Ecology and Conservation Biology, Institute of Plant Sciences, University of Regensburg, 93040 Regensburg, Germany
}

\section{ARTICLE INFO}

\section{Article history:}

Received: $7^{\text {th }}$ July 2015

Accepted: $30^{\text {th }}$ December 2015

\section{Key words:}

climate optima

climate pessima

climate change

central European landscape

habitat diversity

species diversity

\begin{abstract}
$A B S T R A C T$
Climate optima, but also climate pessima, are shown to have strongly affected the origin of settlement in central Europe and the development of the man-made landscape and its habitat and species diversity. Driving forces for climate changes, until recently, were fluctuations of solar activity and radiation, but also comet impacts and volcano eruptions. It could be shown that climate optima increased landscape, habitat and species diversity as well as the expansion of open man-made habitats.

Four climate optima were identified to have had a strong impact. In the Neolithic Age the climate optimum favoured the settlement of people which created the first man made habitats, arable fields, pastures and heathlands. High precipitations resulted in the expansion of wetlands and the origin of raised bogs. In a short climate optimum period in the Bronze Age Alp farming started creating new habitats through e.g. grazing practices. The climate optimum which started at the end of the Iron Age resulted in the first diversity revolution in the landscape during the following Roman Empire Period. Meadows, orchards and vineyards were established. Archaeobotanical remains have shown that during the Roman period most new species/100 years have established in arable fields and grasslands. The medieval climate optimum finally resulted in the largest expansion of open man-made habitats but also new habitats such as fish ponds.

In contrast, during climate pessima abandonment of man-made habitats occurred. During the Migration Period and the Little Ice Age starting at the end of the Medieval Period forests increased. During the climate pessima in the Bronze Age we had the lowest number of new species/100 years.

Actually, through recent laws concerning renewable resources as a reply to the recent climate warming, landscape is changing again.
\end{abstract}

\section{Introduction}

Sedentism and the development of the first man-made landscape started about 12,000 years ago in the Fertile Crescent. First, starting with the collection of wild cereals, plants were domesticated while at the same time hunting still continued. Only after the dramatic falls in game populations (dorcas and Cuvier's gazelles) about 11,000 years ago did the domestication of animals start (Hillman 1996; BarYosef 1998; Hillman et al. 2001; Zeder 2005; 2008). The causes for these processes were probably of multiple origins (Zeder 2006). They may have been a lack of resources due to an increasing population density (Cohen 1977; Binford

*Corresponding author. E-mail: peter.poschlod@ur.de
2001; Winterhalder, Kennett 2006; Watkins 2007), the change of social organization and ideology of the people (Cauvin 2000; Hodder 2001) or simply the discovery of the process of fermentation and the need of the drug alcohol (Reichholf 2008; Dietrich et al. 2012). However, the climate amelioration 11,500 years ago, from a postglacial to a Mediterranean climate with drier summers and wet winters and springs might have played the most important role (McCorrsiton, Hole 1991; Hillman 1996; Richerson et al. 2001; Gupta 2004). Richerson et al. (2001) claim that only stable Holocene climates allowed the evolution of agriculture.

Climate change, in that case a drought in western Asia between 8500 and $8000 \mathrm{BP}$, probably around $8200 \mathrm{BP}$ and therefore also known as 8200 BP event (Alley et al. 1997; see also Figure 1), was also responsible for the migration of farmers from the centre of Fertile Crescent to the west 


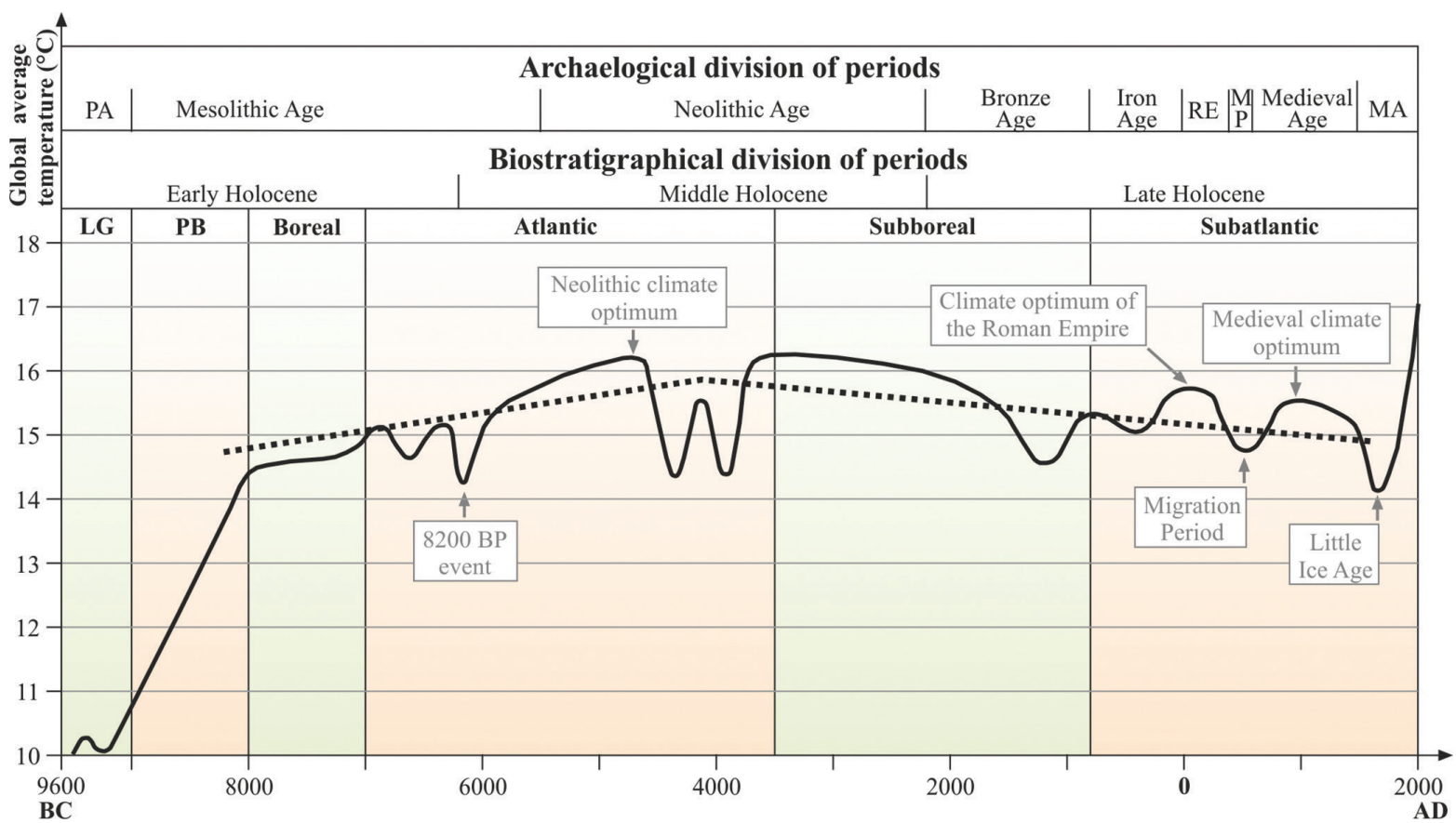

Figure 1. Global average annual mean temperature trend during the Holocene after Schönwiese (1995) and Eitel (2007). Dotted line: Trend reversal in the temperature pattern during the Atlantic Period. PA - Palaeolithic, RE - Roman Empire period, MP - Migration period, MA - Modern Age, LG - Last glacial, PB - Preboreal.

(Weninger et al. 2006; Berger, Guilaine 2008; Clare et al. 2010). The movement started at many places at the same time (Özdoğan 2002; 2011). Özdoğan (2002) described this process as following: "Almost of a sudden we start seeing more habitation, (...) not only in Central Anatolia, but also in the Western Aegean regions, to be accompanied quickly by the Balkans. (...) the number of Pottery Neolithic sites increases dramatically, and almost all of a sudden. In the East, however, there is a decrease in the number of settlements, or the existing ones become smaller (...)... there must have been an endemic movement which started (...) towards the end of the Pre-Pottery Neolithic B. There must have been some kind of beginning stage of this westward movement. There is clearly a kind of a momentum to migrate in masses before the end of the thing. (...) All of a sudden you see that people are moving."

The flooding of the Black Sea through the Bosporus by the rising level of the Mediterranean Sea, often synonymous with Noah's flood (Ryan, Pitman III 1998; Haarmann 2003; 2011; different dating of the start of flooding, earliest moment around $8500 \mathrm{BC}$, latest $5600 \mathrm{BC}$, see Poschlod 2015), might have caused another movement (Milisauskas 2011). However, the date, height and rate of the flooding are still under debate (Ryan et al. 1997; 2003; Bahr et al. 2006; Yanko-Hombach et al. 2007; Giosan et al. 2009; Lericolais et al. 2009; Thom 2010).

Also, the origin of the man-made landscape in central Europe around $5500 \mathrm{BC}$ started during a climate amelioration (Schönwiese 1995; Gronenborn, Sirocko 2010; see also Birks 2003 etc.) caused partially by an increased sun activity which started already in the Mesolithic Age (Steinhilber et al. 2009). The first farmers belonging to the LBK culture spread quite fast from the southeastern edge of central Europe and even Anatolia during this climate optimum which was shown through recent molecular studies of early LBK populations (Haak et al. 2010). Genetic discontinuity to the Mesolithic hunters supports the hypothesis that the first farmers were immigrants (Bramanti et al. 2009; Malmström et al. 2009).

Since then the climate has changed in central Europe (see also Figure 1). Several climate optima and pessima have been described by several authors which, have had clear and distinct impacts on the history of mankind and its cultures (Lamb 1995; Le Roy Ladurie 2004; 2006; 2009a; 2009b; 2009c; Blümel 2006; Behringer 2007; Sirocko 2010). However, climate also affected land use and land use intensity (Bork et al. 1998; Bork 2006) and therefore the man-made landscape, the origin and development of habitats as well as their species diversity (Poschlod 2015). The latter were only reviewed on a local or regional level for certain periods (e.g. Zolitschka et al. 2003) but not for the whole time span since settlement started. This is therefore the aim of this review. Furthermore, the most recent knowledge on the causes of each particular climate change was included.

\section{Climate and the origin of sedentism in central Europe}

The first climate optimum after the last ice age started around $6000 \mathrm{BC}$ and lasted until $3250 \mathrm{BC}$ (Figure 1; Table 1). Causes were an increased solar activity at the beginning and an increased solar radiation during this period (Steinhilber et al. 2009; Nussbaumer et al. 2011).

Warmer temperatures permitted a much higher treeline than today. In the central Austrian Alps the treeline laid at 
Table 1. Characterization of the climate and its chronological classification into zones and respective archaeological and historical epochs. Historical and climate data after Poschlod (2015), mainly according to Schönwiese (1995) and Nelle (2002); biostratigraphical zones after Mangerud et al. (1974) ${ }^{1}$ and Walker et al. (2012) ${ }^{2}$.

\begin{tabular}{|c|c|c|c|c|c|}
\hline $\begin{array}{l}\text { Biostratigraph. } \\
\text { zone }^{1}\end{array}$ & $\begin{array}{l}\text { Biostratigraph. } \\
\text { zone }^{2}\end{array}$ & Archae & logical/historical epochs & $\begin{array}{l}\text { Year BC/ } \\
\text { AD }\end{array}$ & Characterisation of the climate \\
\hline \multirow{9}{*}{ 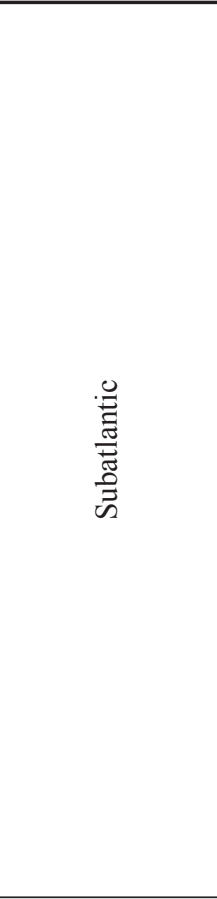 } & \multirow{13}{*}{ 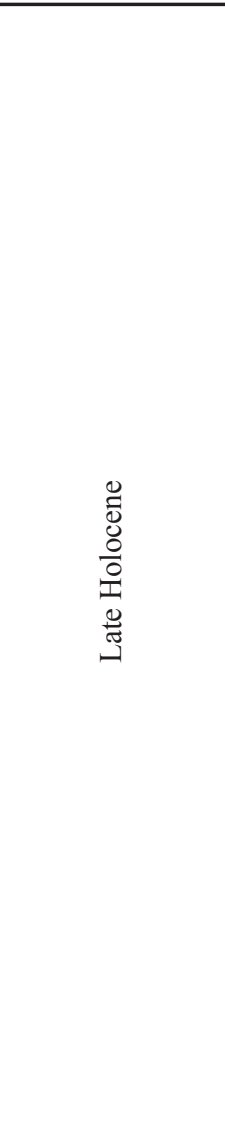 } & \multirow{2}{*}{$\stackrel{\leftrightarrow}{\stackrel{\leftrightarrow}{\Sigma}}$} & $\begin{array}{l}\text { Modern Times } \\
\text { (“Anthropocene") }\end{array}$ & Today & $\begin{array}{l}\text { "Modern climate optimum": the warm } \\
\text { epoch since the mid- } 20^{\text {th }} \text { century, relatively } \\
\text { dry. }\end{array}$ \\
\hline & & & $\begin{array}{l}\text { Early Modern Times } \\
\text { (M.T.) }\end{array}$ & 1750 & \multirow{2}{*}{$\begin{array}{l}\text { Climate pessimum "Little Ice Age" } \\
\text { (1300 to } 1850 \mathrm{AD}) \text { : starting with extreme } \\
\text { weather events in the } 14 \text { th century, cooling; } \\
\text { especially harsh winters, fluctuating } \\
\text { precipitation. }\end{array}$} \\
\hline & & \multirow{4}{*}{ 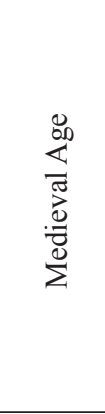 } & Late Medieval Age & 1500 & \\
\hline & & & Medieval Age & 1300 & $\begin{array}{l}\text { Climate optimum (1000 to } 1300 \mathrm{AD}) \text { : } \\
\text { warming, first with low precipitation, later } \\
\text { with high precipitation; expansion of the } \\
\text { man-made landscape into the mountains and } \\
\text { of viniculture to northern Europe. }\end{array}$ \\
\hline & & & Early Medieval Age & 1000 & \multirow{2}{*}{$\begin{array}{l}\text { Climate pessimum ((350)450 to } 750 \\
\text { AD): cooling, high precipitation; glacial } \\
\text { advances. }\end{array}$} \\
\hline & & & Migration Period & 500 & \\
\hline & & 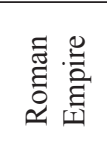 & Roman Empire period & 350 & \multirow{2}{*}{$\begin{array}{l}\text { Climate optimum ( } 300 \mathrm{BC} \text { to } 350 \mathrm{AD}) \text { : } \\
\text { warming, mostly high precipitation; some } \\
\text { Alpine crossings also in winter without } \\
\text { snow; at the end of the period drier; } \\
\text { expansion of viniculture to northern Europe. }\end{array}$} \\
\hline & & \multirow{2}{*}{ 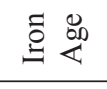 } & La Tène period & 0 & \\
\hline & & & Hallstatt period & 500 & \multirow{2}{*}{$\begin{array}{l}\text { Climate pessimum ( } 1200 \text { to } 600 \mathrm{BC}) \text { : } \\
\text { Cooling - coldest epoch since the last } \\
\text { ice age; cool summers, mostly high } \\
\text { precipitation; many glaciers advance. }\end{array}$} \\
\hline \multirow{6}{*}{ 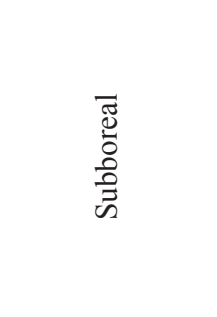 } & & $\underset{0}{\infty}$ & Urnfield period & 800 & \\
\hline & & त्๊ & Late Bronze Age & 1200 & Mainly warm epoch but distinct \\
\hline & & $\ddot{\oplus}$ & Bronze Age & 1300 & fluctuations, less precipitation than in the \\
\hline & & & Early Bronze Age & 1800 & following climate pessimum. \\
\hline & \multirow{5}{*}{ 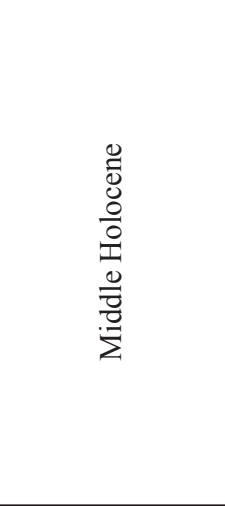 } & \multirow{3}{*}{ 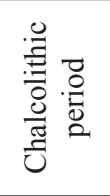 } & Late chalcolithic period & $2200-2300$ & \multirow{3}{*}{$\begin{array}{l}\text { End of climate optimum from } 3400 \mathrm{BC} \\
\text { onwards: cold epoch with glacial advances } \\
\text { (Piora oscillation); in the beginning with } \\
\text { low precipitation, later increasing; "Ötzi" as } \\
\text { indicator of the glacial advance. }\end{array}$} \\
\hline & & & Chalcolithic period & 2500 & \\
\hline \multirow{3}{*}{ 总 } & & & Early chalcolithic period & 3500 & \\
\hline & & 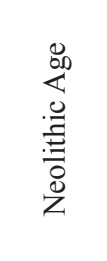 & Neolithic & $\begin{array}{l}4400 \\
(\mathrm{NCE})\end{array}$ & \multirow[t]{2}{*}{$\begin{array}{l}\text { Start of the Neolithic Age in southern } \\
\text { central Europe (SCE) from } 5500 \text { BC } \\
\text { onwards, in northern central Europe (NCE) } \\
\text { only from } 4000 \text { BC. Climate optimum (ca. } \\
6000 \text { to } 3400 \text { BC): warmest epoch since } \\
\text { the last glacial period, very mild winters, } \\
\text { high precipitation; start of human settlement } \\
\text { ("Neolithic revolution"). }\end{array}$} \\
\hline & & \multirow{3}{*}{ 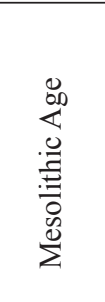 } & Late Mesolithic & 6000 & \\
\hline Boreal & \multirow{2}{*}{ 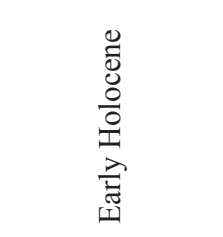 } & & \multirow{2}{*}{ Early Mesolithic } & 7000 & $\begin{array}{l}\text { Summers mostly warmer than today, mild } \\
\text { or very cold winters; low precipitation. }\end{array}$ \\
\hline Preboreal & & & & 8000 & Summers warm, winters very cold. \\
\hline \multirow{3}{*}{ 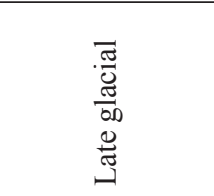 } & \multirow{3}{*}{ 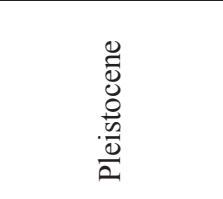 } & \multirow{3}{*}{ 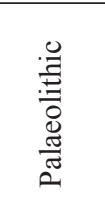 } & \multirow[b]{2}{*}{ Epipalaeolithic } & 9600 & Cold epoch. \\
\hline & & & & & $\begin{array}{l}\text { Transition of the last cold epoch to the } \\
\text { warm interval. }\end{array}$ \\
\hline & & & Upper Palaeolithic & & End of the last cold epoch. \\
\hline
\end{tabular}




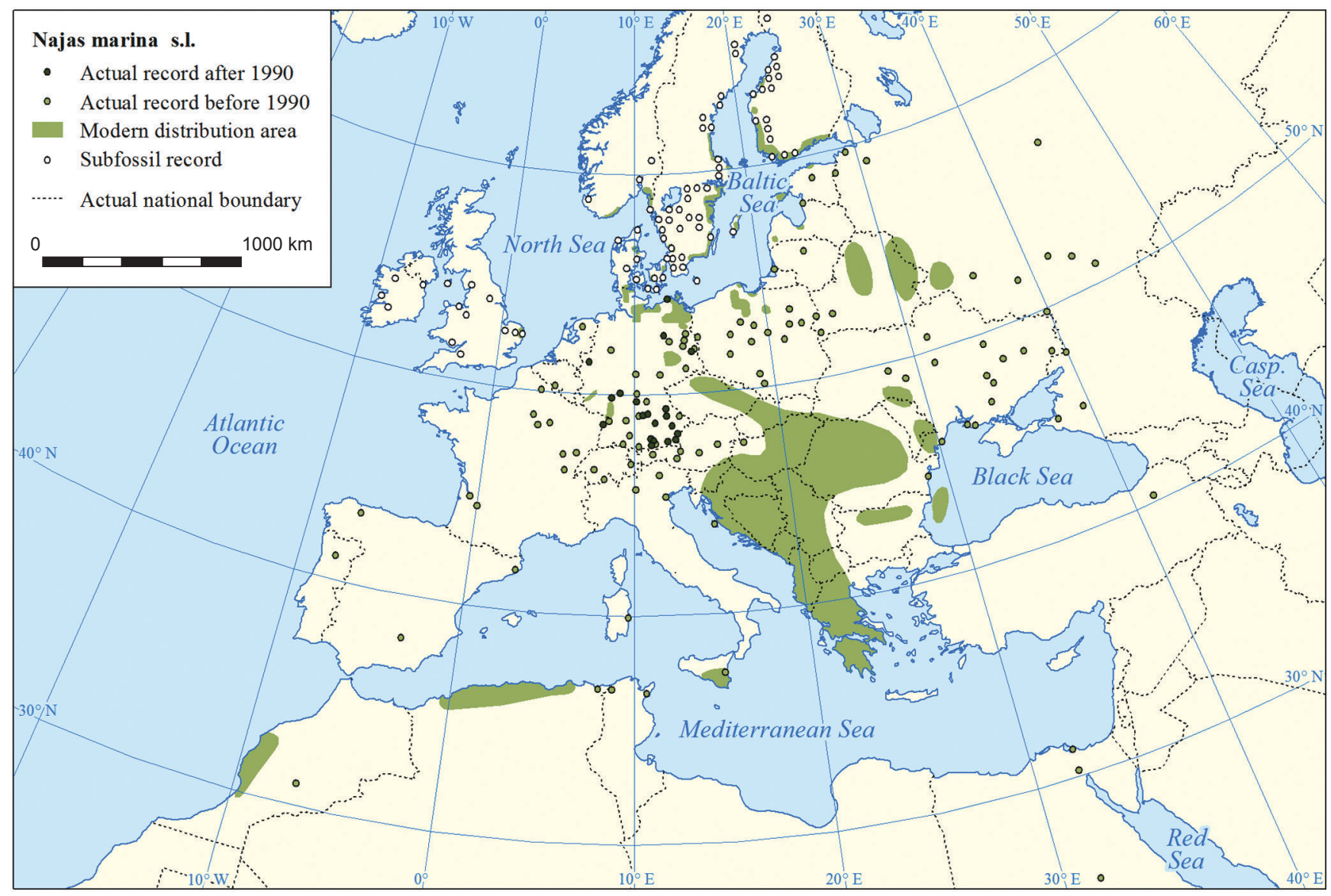

Figure 2. Historical and recent (before 1990 and after 1990) distribution of Najas marina s.l. (historical data and actual data until 1990 after Lang 1994 , actual data after 1990 after Poschlod 2015).

2,400 m a. s. 1. compared to 2,250 m a. s. 1. in 1980 (Nicolussi et al. 2005). Subfossil remains from thermophilic aquatic plants, such as Trapa natans (von Post 1946; Hultén, Fries 1986; Lang 1994) as well as Najas marina agg. (Figure 2) and N. flexilis (Godwin 1975; Lang 1994), but also from animals such as the European pond turtle (Emys orbicularis; Degerbøl, Krog 1951; Sommer et al. 2007; 2009), reveal that they reached their most northern distribution since then.

High precipitation initiated the start of the development of ombrotrophic from minerotrophic- or groundwater-fed mires; the origin of most raised bogs in central Europe date from this period (Paul, Ruoff 1932; Overbeck 1975; Couwenberg et al. 2001). The increased discharge of calcareous springs in combination with high temperatures led to the formation of large meteogenous travertine or tufa deposits (Pentecost 1995; Ford, Pedley 1996) e.g. in the Bohemian Karst (Ložek 1961; 1963; 1964; Starkel 1966) or in the Jurassic mountains of the Swabian Alb (Groschopf et al. 1952) and its respective habitats. At the end of the Neolithic age precipitations increased again (often called pluvial period; Schönwiese 1995) which caused an increase in ground water level evident through the increase of paludification and spread of alder carr, for example, in northwest-Germany (Overbeck 1975). For Lake Constance, a strong water level rise has been dendrochronologically dated to $3370 \mathrm{BC}$ (Magny et al.
2006). High precipitation also caused a retreat in pine (Pinus sylvestris) and an increase in common hazelnut (Corylus avellana) in that region. In the south German Federsee, the highest water level was reported at the end of the Neolithic Age. An earlier rise of water level in the Federsee occurred between 4800 and $4500 \mathrm{BC}$ (Wall 1961), in the Lake of Constance between 4600 to 4700 BC (Magny et al. 2006). During both periods, pollen of Cyperaceae, most of their species belonging to wetland plants in central Europe, increased at the Lake Constance (Magny et al. 2006). Water level rises between 6000 and $4000 \mathrm{BC}$ have also been reported from southern Sweden (Harrison, Digerfeldt 1993). Therefore, the first half of the Neolithic period may be also called the wetland expansion period.

At the same time, the favourable climate supported the start of sedentism - resulting in the origin of the first man-made habitats, arable fields and pastures (grasslands, heathlands).

To understand the origin of open habitats and grasslands, respectively, we first have to ask the question: how did the landscape and forests look like around 5500 BC? Until recently, most studies on central Europe claimed that there was already a closed forest cover everywhere below the timberline (Firbas 1949; 1952; Lang 1994; maps of the natural landscape: Schwickerath 1954; Hueck, Behrmann 1962), except in certain specific habitats such as: gravel 
islands in river beds (Osborne 1972; 1997; Ellenberg 1996; Gao et al. 2000); rock formations (Meusel 1935; 1939; Gradmann 1950; Müller 1980); "beaver meadows" (Wells et al. 2000; Schneider 1996; Harthun 1998; 1999); open stages during autogenous cyclic succession in alder carrs (Pokorný et al. 2000; Sádlo 2000); and mires (particularly percolation mires; Succow, Jeschke 1986). In contrast to this hypothesis, Vera (2000) claimed that the forests were partly open. His hypothesis is based on the assumptions that the first megaherbivores, which today are partly extinct, such as the aurochs or the European bison, contributed to more open forests (but see Stuart et al. 2004 and Mitchell 2005). However, besides the megaherbivore hypothesis, there are many other aspects and new results which support the hypothesis of a more open landscape, and more open forests, when the first farmers settled (see also Kreuz 2008):

1. The forests consisted of oak (Quercus spp.), elm (Ulmus spp.), common hazel (Corylus avellana), lime tree (Tilia spp.) and ash (Fraxinus excelsior; Clark et al. 1989). All these species are not so shade-tolerant. Oak, for example, is not able to regenerate by seed under a closed canopy and common hazel would not even flower (Vera 2000). However, the shade-tolerant and most dominant species in the actual potential natural vegetation would be beech (Fagus sylvatica) and fir (Abies alba). Although beech might have already occurred locally in northern Germany before the Neolithic Age (Robin et al. 2016) it has only spread after the first farmers have settled. It may have even immigrated with the first farmers - being an important crop and fodder plant (Bonn, Poschlod 1998) since beech came from the southeast (Slovenia; Magri et al. 2006; Magri 2008) and started to establish only around $5000 \mathrm{BC}$ in southeast Germany (Huntley, Birks 1983; Lang 1994). Fir having come from the south (Konnert, Bergmann 1995; Hewitt 1999) arrived around $4500 \mathrm{BC}$ in southwest Germany (Black Forest; Lang 1994). According to Küster (1997), beech is a synanthropic species, an idea that has recently been confirmed for Bohemia, through its asynchronous immigration (Pokorný 2005), and the northern part of central Europe (Tinner, Lotter 2006), but declined for Switzerland and southern Germany (Tinner, Lotter 2006).

2. Fire might have played a further role by maintaining open landscapes/forests. The high proportions of common hazel pollen may have been caused through natural fires (Clark et al. 1989). Alternatively, fire might have been used by Mesolithic people to increase common hazel as an important fodder plant (Bos, Urz 2003). For North America, natural or man-made fires have also been discussed as having maintained oak forests (Abrams 1992).

3. Recently, studies from the Czech Republic have shown that forests had not reached their maximum expansion during the beginnings of settlement (Hájková et al. 2011) and that there were continuous grassland habitats (forest steppe) represented today by semi-natural grasslands (Kuneš et al. 2015; Pokorný et al. 2015).

4. Phylogeographic studies on grassland plants, despite having their main distribution in a Mediterranean climate, such as Eryngium campestre, have shown that they may have survived in central Europe in (micro)refugia (Bylebyl et al. 2008; see also Poschlod 2015).

Evidence of arable fields has come from pollen analysis and seed remains in Neolithic settlements, and of grasslands from pollen and pedoanthracological analyses. One exception has been the findings of plant macroremains (vascular plants, bryophytes) in the sods of a Celtic grave mound (Fritz 1977; 1979; Fritz, Wilmanns 1982).

Arable fields mainly developed from slash and burn, but also through clearing, and only rarely after wood pasturing

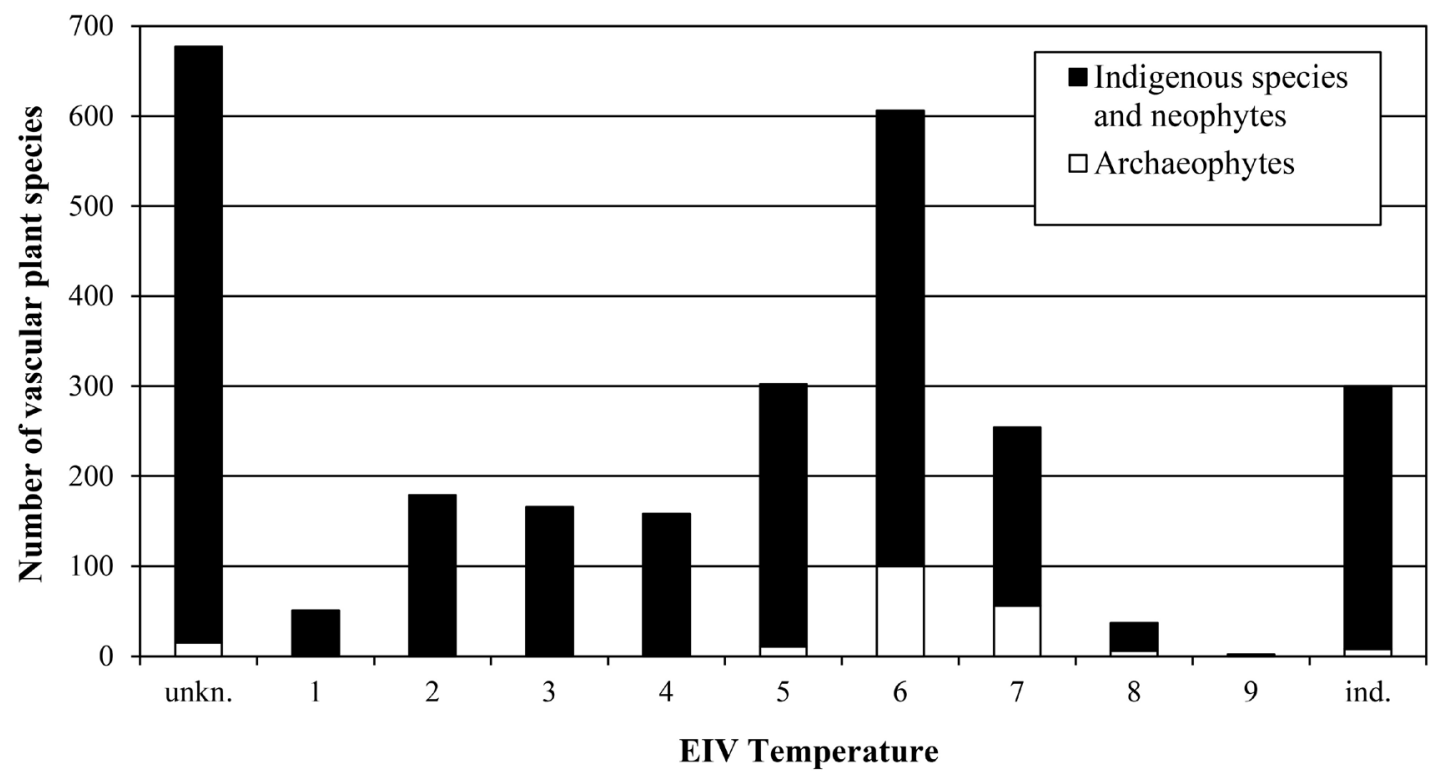

Figure 3. Proportion of archaeophytes, indigenous species and neophytes (in Bavaria) at each temperature indicator value category according to Ellenberg (Ellenberg et al. 1991). Ellenberg indicator values define a species' niche along an environmental gradient, in this case temperature (or altitude): 1 - alpine, nival to 9 - very warm, colline; Ind - indifferent species (not indicating a specific niche along a temperature/altitudinal gradient). 
Era

\begin{tabular}{|c|c|c|c|c|c|c|c}
\hline Nordic & Bronze & Iron & RE & $\begin{array}{c}\text { Early } \\
\text { Neolithic Age }\end{array}$ & Age & $\begin{array}{c}\text { Modern } \\
\text { Age }\end{array}$
\end{tabular}

\section{Number of pollen}

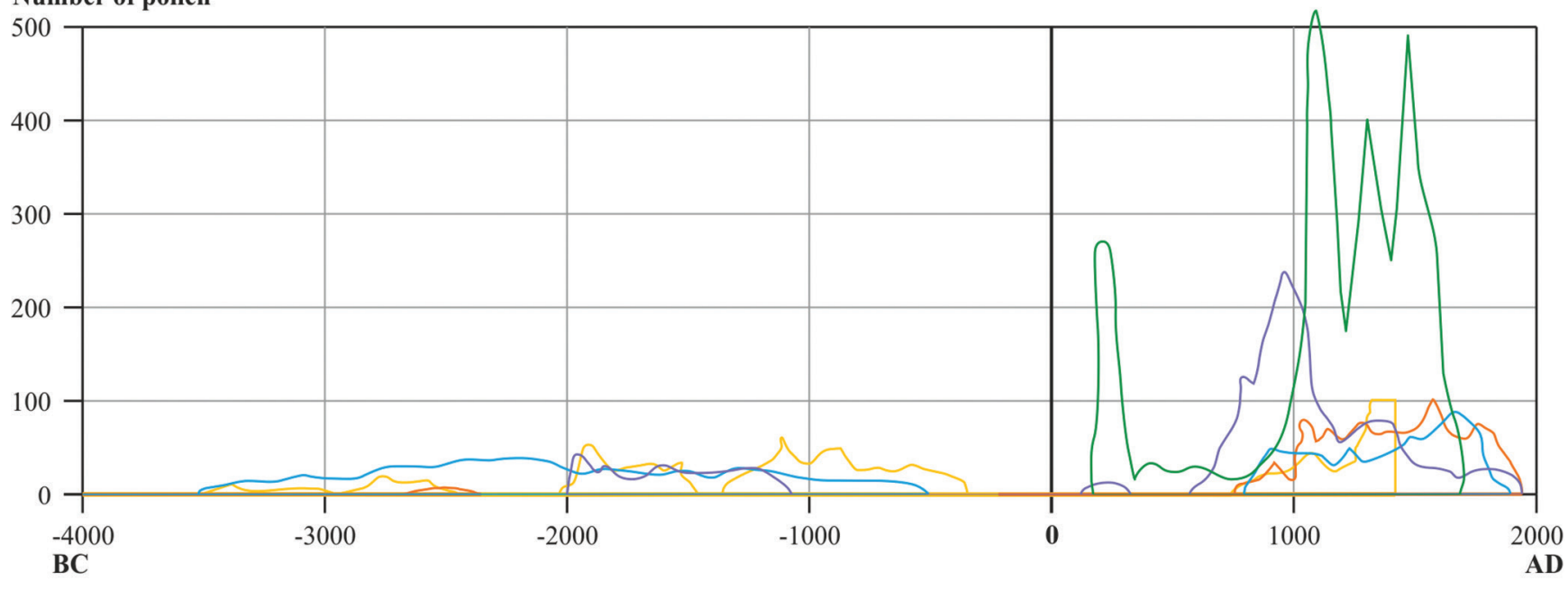

- Pietzmoor $\quad$ Voßmoor $\quad$ Mire at Heidegrund $\quad$ Höpeler Ponds $\quad$ Mire at Undeloh

Figure 4. Chronological development of heathland and its expansion in the Luneburg heath (northwest Germany) based on pollen data of Calluna vulgaris from different peatland localities in this region (after Pott 1999). RE - Roman Empire period; MP - Migration period.

(Roberts 1998; Behre 2008). The first crops were einkorn, emmer, barley, pea, lentil, flax and poppy, crops which evolved in a Mediterranean climate. In central Europe they were grown as summer crops, meaning that they were sown in spring and harvested during summer (Willerding 2003a). This allowed the arable fields to be grazed after harvesting until the next spring. Thus the fields were fertilized and could be managed over longer periods (Kreuz, Schäfer 2011). Arable fields were often managed on a long-term basis without alternating grassland use (Knörzer 1986), since the first settlements of LBK people were established in regions with fertile loess deposits (Jankuhn 1969). This hypothesis of naturally fertile soils is supported through the records of nutrient-demanding or nitrogenindicating species in the cereal remains of the earliest LBK settlements, such as: Bromus secalinus, Chenopodium album, Galium aparine, G. spurium, Lapsana communis, Phleum pratense, Fallopia convolvulus, Setaria spp., Solanum nigrum (Bogaard 2002; 2004; Kreuz, Schäfer 2011). Nevertheless, depending on the region and soils, either agroforestry, or alternate arable field-grassland and arable field-forest use, or shifting cultivation, have also occurred (Rösch 1990; 1991; Schier 2009). The vegetation of this plant community was composed of indigenous species, but also archaeophytes that came from regions with a Mediterranean climate either from the Near East, Asia Minor or southeast Europe. At least 27 archaeophytes arrived during the Neolithic Age via uncleaned crop seeds, although some might also have been used as fodder plants (Poschlod 2015). Still today, arable weed communities contain the highest proportion of archaeophytes (Willerding 1986). Archeophytes are a reflection of warm climatic conditions through their temperature indicator value which is above average compared to that of the whole central European flora (Figure 3).
Grazing either in forest steppe grasslands, or in more-orless open forests, and in arable fields after their abandonment, resulted in the first "man-made" grasslands. Few palynological studies have shown a continuous existence of calcareous grasslands in northern or northwest Europe since the Neolithic Age (Königsson 1968; Bush 1993; Preece, Bridgland 1999). Applying pedoanthracological analyses, Dutoit et al. (2009) supposed the establishment of calcareous grasslands for western Europe, in the Seine valley (Upper Normandy, France), through forest clearing by fire around 4800 to 4600 BC. For eastern central Europe, Hájková et al. (2011) have shown that actual, extremely species-rich grasslands, or those with a high number of socalled relict species, were always situated in the vicinity of Neolithic settlements and concluded from this fact that the continuous management since then has maintained this high species-richness (Kuneš et al. 2015; Pokorný et al. 2015). In Germany, the existence of man-made grasslands has been proved from at least the Bronze Age (Poschlod, Baumann 2010), or the Iron Age (Fritz, 1977; 1979; Fritz, Wilmanns 1982).

Heathlands were first verified in north Germany (Behre 2008) for the period of the Funnel Beaker culture (4100 to 2800 BC; Müller 2011). The first evidence for heathlands in the famous Luneburg heath dates back to around $3500 \mathrm{BC}$ (Pott 1999; Figure 4).

\section{The first climate pessimum period from the end of the Neolithic Age to the start of the Iron Age}

At the end of the Neolithic period, around $3400 \mathrm{BC}$, the climate optimum ended and temperatures cooled down. The 


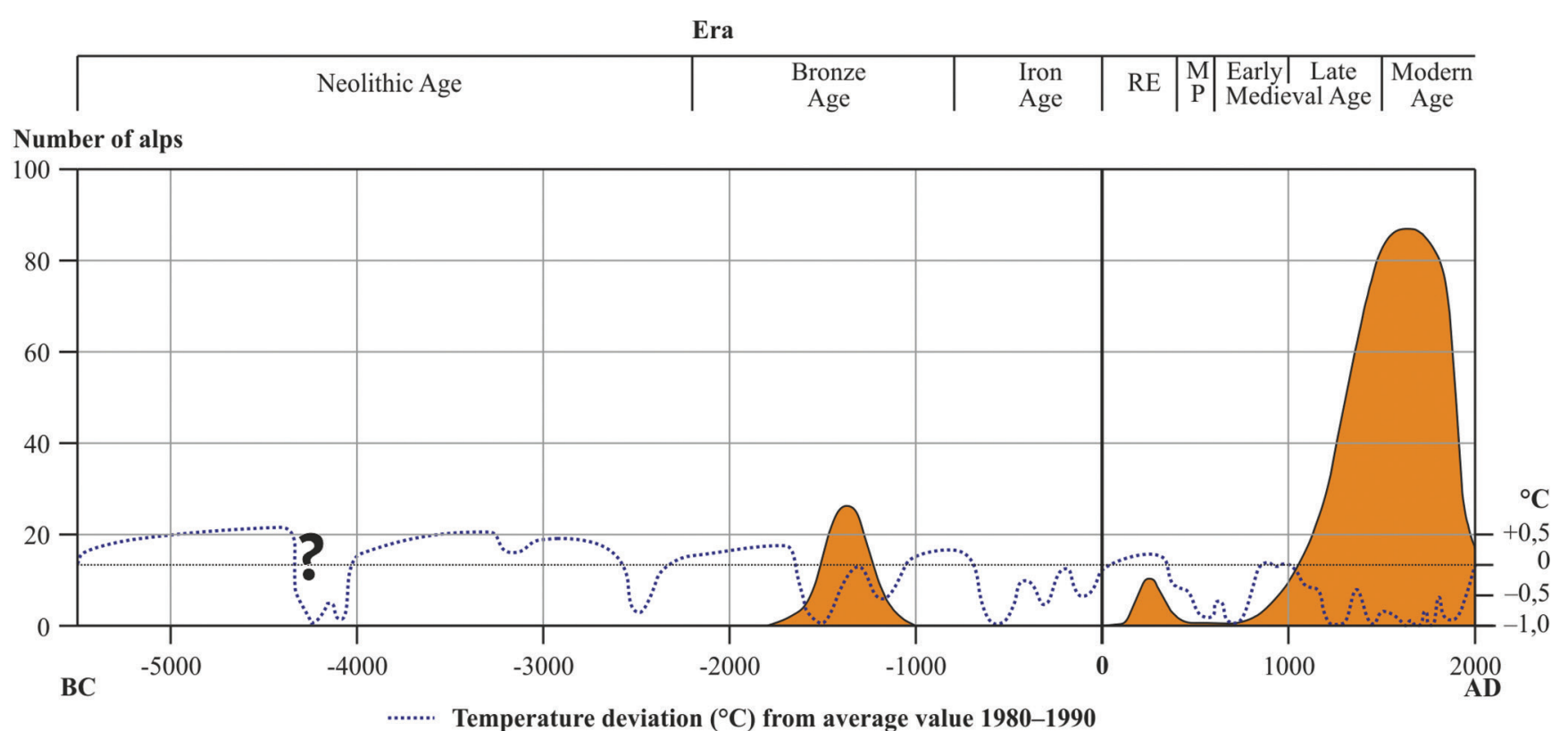

Figure 5. Temperature trend (blue dotted line) and origin of alpine farming/number of alps in the Dachstein mountains (Austria; after Mandl 2009). RE - Roman Empire period; MP - Migration period.

following cold period, called Piora Oscillation (around 3400 $\mathrm{BC}$ to $3000 \mathrm{BC}$; Zoller 1960), caused a decline of the tree line (Frenzel 1966; Wick, Tinner 1997; Nicolussi et al. 2005) and an expansion of the glaciers in the Alps (Joerin et al. 2006), as well as a decrease in the dominant tree species Tilia and Ulmus (Lang 1994). Temperatures in central Europe were around 1 to $2^{\circ} \mathrm{C}$ lower (Amesbury et al. 2008; Bleicher, Sirocko 2010). The causes for the cooling are not clear and may have been influences from orbital change of the earth around the sun, a decrease of solar activity, or the expansion of polar sea currents (Magny et al. 2006). Ötzi, the "iceman", who was found at $3210 \mathrm{~m}$ a. s. 1, is the most famous indicator of this cool period (Baroni, Orombelli 1996; Fleckinger 2011; Magny, Haas 2004).

Probably he was a migrating herder (Hollemeyer 2008), the hypothesis being supported through isotope analyses of his teeth and bones (Müller et al. 2003). This would also indicate transhumant herding in the central Alps, a finding which was already proven for the Neolithic Age and Bronze Age in the Mediterranean region, the Pyrenees and the central Alps through archaeological findings (Mandl 2007a; 2007b; Reitmaier 2009), soil layers indicating slash and burn (Reitmaier, Walser Bakk 2008), pedoanthracological findings (Wick, Tinner 1997; Talon et al. 1998), dung deposits (Akeret, Jacomet 1997; Akeret et al. 1999) and pollen analysis (Drescher-Schneider 2009).

In contrast to transhumant herding, alpine farming only appeared for first time during the Bronze Age. The oldest proven incidence is from the Dachstein mountains where it started around 1700 BC (Mandl 2009) at the beginning of a short climate optimum (Figure 5). Transhumant herding, as well as alpine farming, during that period have strongly contributed to the decline of forests of Larix decidua and Pinus cembra and, as a consequence, to the lowering of the tree line. New habitats developed - such as the "Larix pastures". Pasture weeds such as Rhododendron spp. and Alnus viridis increased (Zoller 1960; Tinner et al. 1999, 2003; Gobet et al. 2004). Today, the Rhododendron belts above the tree line often represent ancient abandoned pastures (Ellenberg 1996; Anthelme et al. 2003). Alnus viridis was also favoured through the application of fire (Gobet et al. 2003). Transhumant and alpine farming may have strongly contributed to the enrichment of lowland grassland biodiversity through the transport of seeds from higher to lower altitudes by domestic livestock, but it also probably occurred in the opposite direction (Poschlod, Bonn 1998; Poschlod 2015).

After the first cold epoch and the short optimum which lasted until $1200 \mathrm{BC}$, another climate pessimum started which was probably the coldest since the last ice age (Table 1). One cause might have been the outbreak of the Hekla volcano in Iceland (Baker et al. 1995; Yurco 1999; Eiríksson et al. 2000). Glaciers expanded again (Holzhauser et al. 2005) and alpine farming was abandoned (Mandl 2009). Crop failures and food supply problems may have been the stimulus for novelties and technological progress. Robust crop plants such as spelt (Triticum spelta; from Asia Minor), foxtail millet (Setaria italica) and common millet (Panicum miliaceum; both from East Asia) (Crawford 2005; Nasu et al. 2007; Zohary et al. 2012), as well as the fava bean (Vicia faba, from Asia Minor; Tanno, Willcox 2006), were increasingly cultivated. However, according to Rösch and Heumüller (2008), the cultivation of these plants might have been as a consequence of the nutrient-impoverished soils, due to the permanent application of fire during shifting cultivation (slash and burn agriculture). Speier (1994) assumed that the increase of pollen of wet grassland plants around $1000 \mathrm{BC}$ indicates the start of hay making. 


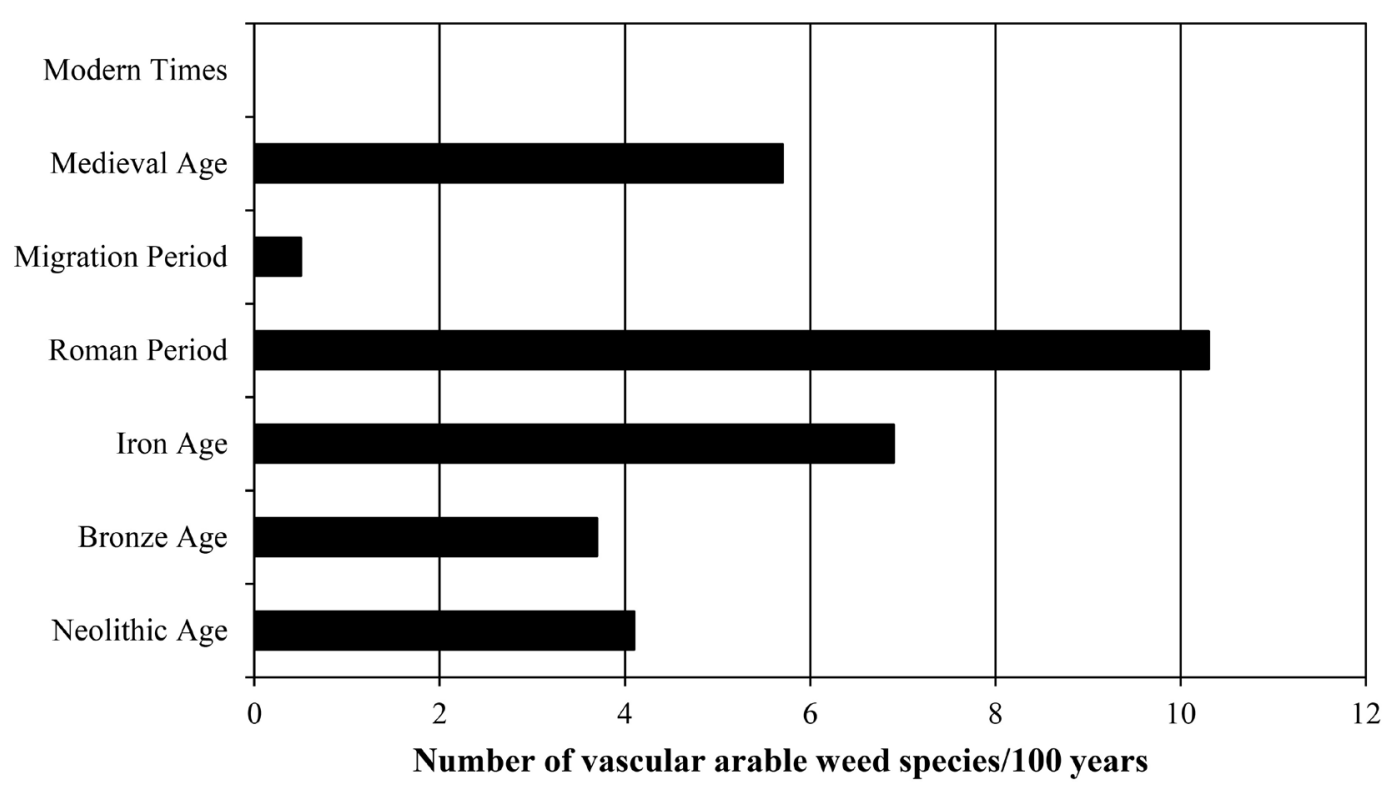

Figure 6. Number of new arable weed species (per 100 years) in archaeobotanical findings of central Europe for each archaeological/historical period (after Willerding 1986).

However, his indicator species - such as sedges, marshmarigold (Caltha palustris), lesser spearwort (Ranunculus flammula), bistort (Bistorta officinalis), Devil's bit (Succisa pratensis) and thistles (Cirsium spp.) - also occur on wet pastures. Grazing was still the main land use within wetland areas until the $18^{\text {th }}$ century. According to Hodgson et al. (1999), who used a functional approach, the earliest meadow use was in the Iron Age where the first scythes were found (Leube 2003). In southern Germany, grassland species only increased in the Iron Age, which was interpreted as a signal of permanent open land or grassland (Rösch, Heumüller 2008). In the eastern part of Europe which was settled by Slavic people, meadow use only started as late as the Medieval Age (earliest $11^{\text {th }} / 12^{\text {th }}$ century, latest $14^{\text {th }}$ century; Hempel 2008). The Slavs, who immigrated during the Migration Period to the eastern part of central Europe (Brather 2008), did not know the scythe (Hempel 2008).

Taking into account the number of new archaeophytes, the Bronze Age had the lowest increase per 100-year period, not only in arable weeds but also grassland species (Figures 6 to 8).

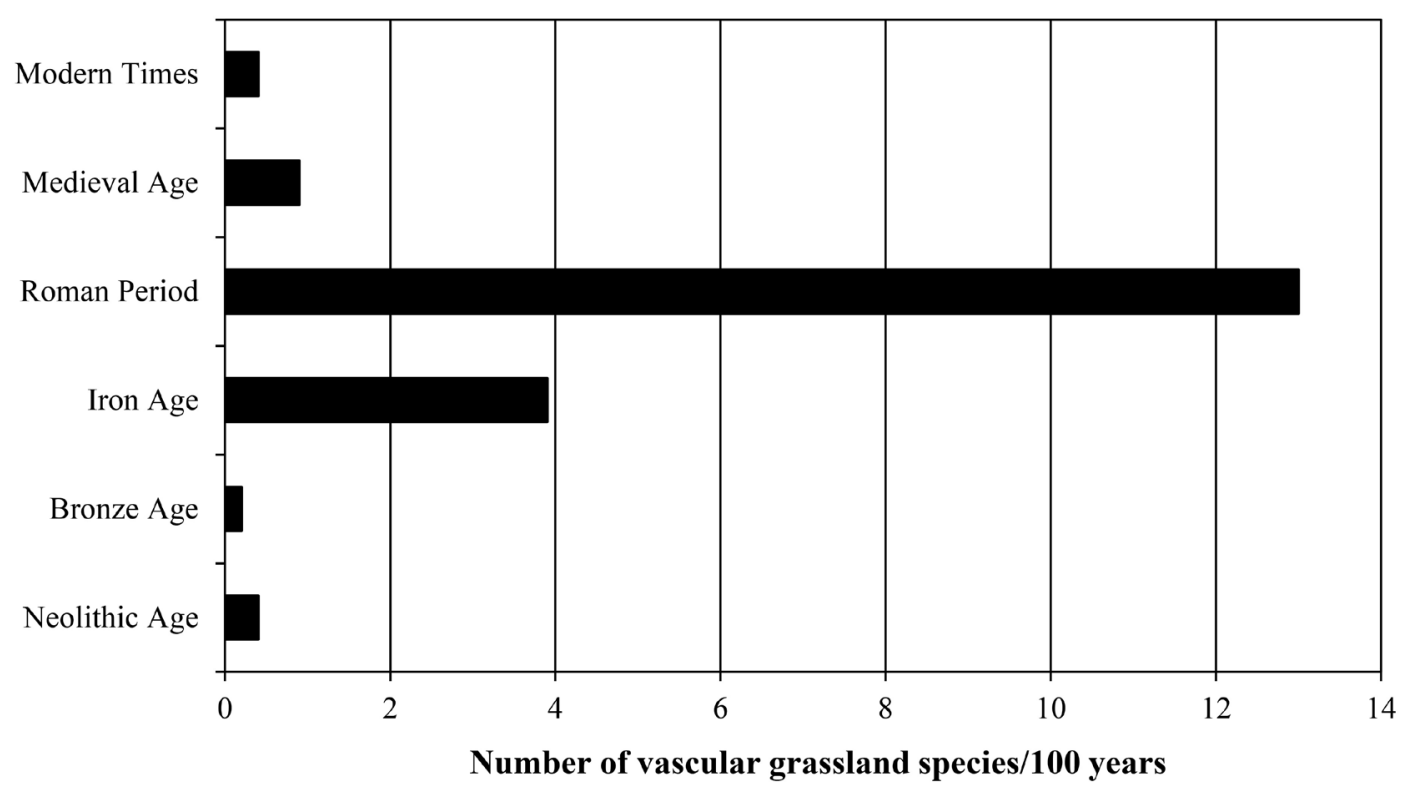

Figure 7. Number of new grassland species (per 100 years) in archaeobotanical findings of the Lower Rhine region for each archaeological/historical period (after Knörzer 1996). 


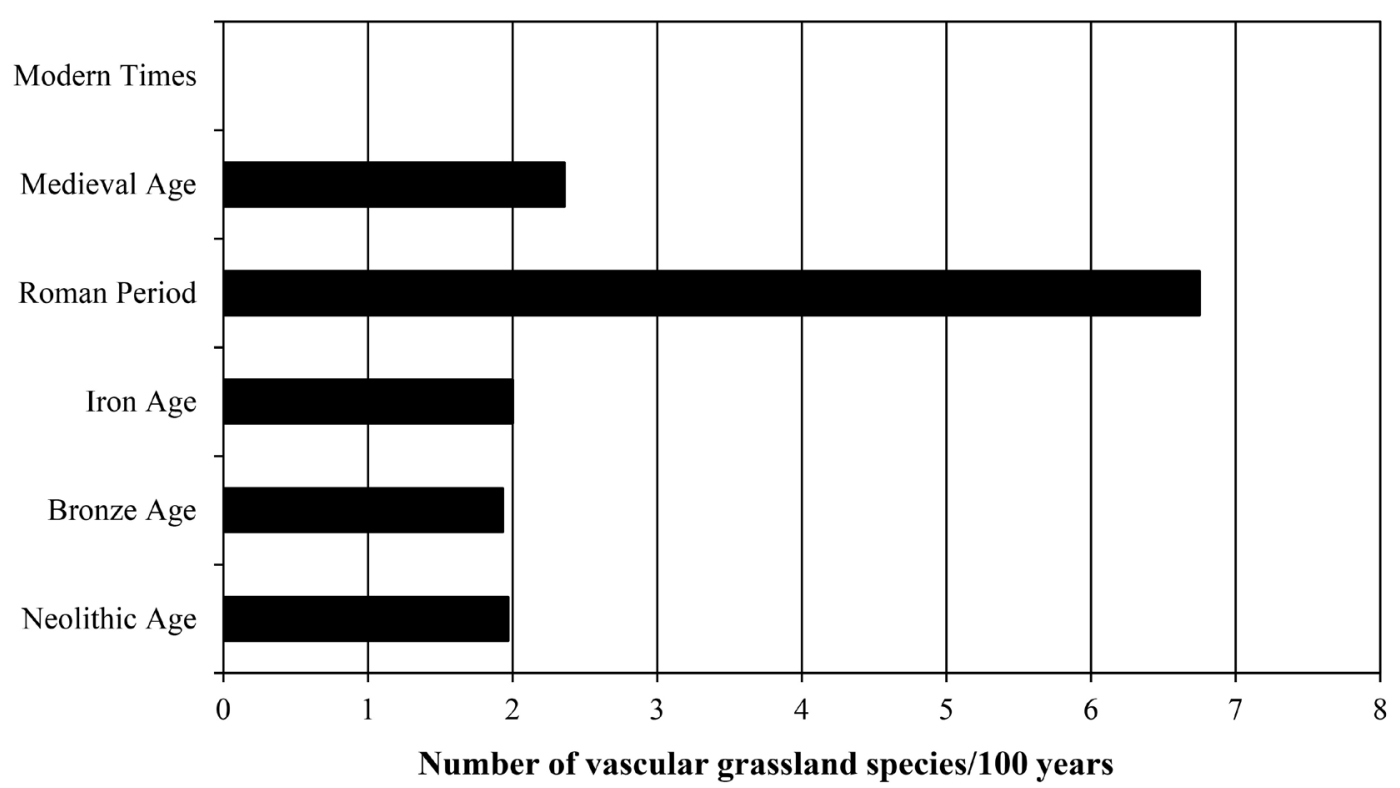

Figure 8. Number of new grassland species (per 100 years) in archaeobotanical findings of northern Switzerland (region around Basel) for each archaeological/historical period (after Jacomet, Brombacher 2009).

\section{The second climate optimum during the Roman Empire period - the first diversity revolution in the man-made landscape}

A new climate optimum followed from around $300 \mathrm{BC}$ to 350 $\mathrm{AD}$ (Figure 9; Ljungqvist 2010). Its main cause was increased sun activity, which at the beginning and end of this period was probably the highest during the Holocene (Steinhilber et al. 2008). According to Crumley (1994), there was an extreme shift of three climatic regions colliding with each other in central Europe - the Mediterranean, oceanic and continental climates. Whereas from $1200 \mathrm{BC}$ to $300 \mathrm{BC}$ the border of the Mediterranean climate was situated to the south of European Mediterranean countries, it moved considerably further north during the following 600 years. At this time, central Europe was mainly covered by forests, as described by Tacitus in his "Germania" in the $1^{\text {st }}$ century: "The land may vary a certain amount in its appearance, but in general it either bristles with forests or festers with marshes. It is wetter on the side facing the Gauls, windier opposite Noricum and Pannonia" (Birley 1999).

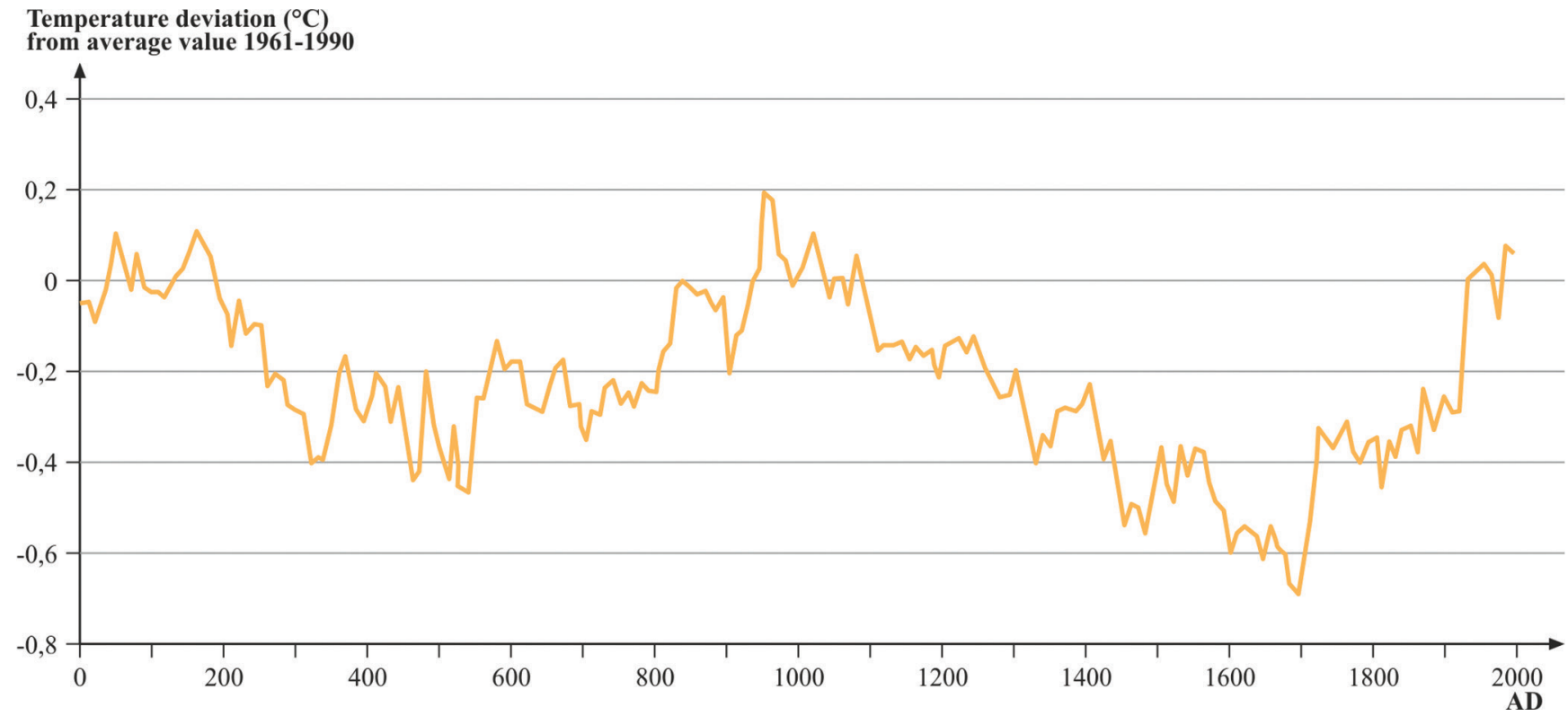

Figure 9. Decade average temperature trend in the non-tropical northern hemisphere ( 90 to $\left.30^{\circ} \mathrm{N}\right)$ between $1 \mathrm{AD}$ and $1999 \mathrm{AD}$ in comparison to the average mean annual temperature between 1961 and 1990 (after Ljungqvist 2010). 
This climate optimum or change was the first to have been documented in written sources and for which hypotheses as to its causes were set up. Columella wrote in his first book on "Agriculture": "For I have found that many authorities now worthy of remembrance were convinced that with the long wasting of the ages, weather and climate undergo a change;... For in that book on agriculture which he (Saserna, a pre-Christian Roman writer; note of the author) has left behind he concludes that the position of the heavens has changed from this evidence: that regions which formerly, because of the unremitting severity of winter, could not safeguard any shoot of the vine or the olive planted in them, now that the earlier coldness has abated and the weather is becoming more clement, produce olive harvests and the vintages of Bacchus in the greatest abundance" (Ash 1941).

Lamb (1977) mentioned a shift in the distribution of beech (Fagus sylvatica) in book XVI of Plinius. However, from the original source there is no evidence.

The climate optimum allowed for a more efficient agriculture in central Europe. It resulted in the first foundation of towns and in the expansion of the Roman Empire. Famous towns founded at the end of the Iron Age were some celtic oppida (Iron Age fortified settlements) such as Manching ( $3^{\text {rd }}$ century BC; Bavaria, Germany) or Bibracte/Mont Beuvray ( $2^{\text {nd }}$ century BC; Rieckhoff, Fichtl 2011; France), and at the beginning of the Roman times, such as Treves/Trier (Augusta Treverorum; RhinelandPalatinate), Augsburg (Augusta Vindelicorum), Kempten in the Allgäu (Cambodunum; Bavaria), Xanten (Vetera; North Rhine-Westphalia) and many more (Thiel 2008).

With the expansion of the Roman Empire the central European man-made landscape within the limites (the empire's frontier limits) became more diverse. Crop rotation was practiced, mainly as a two-field rotation system (Drexhage et al. 2002), but already probably also as threefield rotation system (Küster 1994).

The two-field rotation system consisted of two parts, the arable fields and the fallow which alternated every year (Schröder-Lembke 1978). Locally, the two-field rotation system existed in the Rhine region, especially in Alsace, Palatinate, at the Moselle and at Jülich, until the beginning of the $19^{\text {th }}$ century (Schwerz 1816a; 1816b).

Livestock breeding was so intensely practiced that some authors call it the first agricultural bloom or even "revolution" (Peters 1994). The Romans also brought new animals to central Europe. They domesticated the carp (Cyprinus carpio) which originally occurred in southeast European and Asian rivers running to the Black and Caspian Seas, as well as to the Aral Sea (Balon 1995). Rabbit (Oryctolagus cuniculus; originally distributed in North Africa and Spain) and pheasant (Phasianus colchicus; originally distributed in central Asia) were introduced. Rabbit was probably introduced merely to France and only came to central Europe during the Medieval Ages (Niethammer 1963; Kroll 1973). The edible snail (Helix pomatia) was farmed in so-called "snail gardens". These were a source of food for the Romans, who probably brought it for that purpose to England where it is still called "Roman snail" (Mansfield 2011).

In the vicinity of Roman villas (Villae Rusticae) new habitats developed, such as vineyards and orchards through the import of new crop plants such as fruit trees and vines (Willerding 1992; 2003b). Such fruit included sweet cherry, pear, prune, walnut, apple, plum, peach, apricot and quince (Willerding 2003b; Poschlod 2015). However, the introduction of other new crop plants such as vegetables (lettuce, onion, leek, garlic, chard, common purslane, etc.; Körber-Grohne 1994) and spices (dill, coriander etc.; Knörzer 2004) may have also contributed to an increasing habitat and species diversity. In the regions outside the empire's limits (limites) there has been no evidence of these crop plants (Willerding 2003b).

Tacitus wrote in his Germania in the $1^{\text {st }}$ century AD, that the country "is fertile for sown crops but will not grow fruit trees" and there were neither orchards nor meadows (Birley 1999): "In fact, however, for all that their land is fertile and extensive, they make no effort at planting orchards, fencing off pasturing, or irrigating gardens. Their only demand on the soil is for corn". The taste of the fruit from the wild apple trees was described by Pliny the Elder in his "Naturalis Historia" (Rackham 1945): "There are also wild apples with little attraction of flavour and an even sharper scent; their special fault is that of horrible sourness, and it is so powerful that it will blunt the edge of a sword".

Many German terms in pomiculture and viniculture have therefore Latin roots. In viniculture, these are, for example, "Wein" (wine; from latin vinum), "Winzer" (wine grower; from latin vinitor), "Lämpel", "Lämbel" or "Limbel” (border of the vineyard; from latin limbulus/limbus), "keltern" (wine pressing; from latin calcare), "Keller" (cellar; from latin cellarium), "Legel" (little barrel; from latin lagella). In pomiculture, these are "propfen" (grafting; from latin propagare), "emden", "impten" or "impfen" (inosculation; from latin inserere), "pelzen" (grafting a branch behind the bark; from latin pellis), "Most" (must, newly-pressed juice from grapes/fruit; from latin mustum), "Torkel" (wine press; from latin torcular), "Kufe" (vat; from latin cupa), "Kübel" (bucket; from latin cupella) and, of course, the names of the fruits or fruit trees such as "Kirsche" (cherry; from latin cerasus), "Birne" (pear; from latin pirus) and "Nuss" (nut; from latin nux; Grimm, Grimm 1854-1960; Kleiber et al. 1993; Zehnder, Weller 2006).

The agricultural diversity resulted in the highest increase in "new" (archaeophytic) arable weed as well as grassland species per 100 year period ever since then (Figures 6 to $8)$. For the arable weeds, the main reason was certainly the cultivation of new crop plants (Willerding 1986; Lang 1994; Knörzer 2004; Jacomet, Brombacher 2009). For the grassland plants, the beginning of the application of mowing might have been one reason (Knörzer 1979; Körber-Grohne 1983; 1990; but see Hodgson et al. 1999), but also the introduction of hay (for example, for the horses of the cavalry) at least at the beginning of the Roman conquering expedition. According to Kronfeld (1919), the 
Figure 10. Number of (sub)mediterranean species in historical relevées from Gauckler (1938) of calcareous grasslands in southeast Germany in relation to the distance of the Roman limes (significant decrease with increasing distance to the limes; $\mathrm{p}<0,05$; from Baumann 2006)

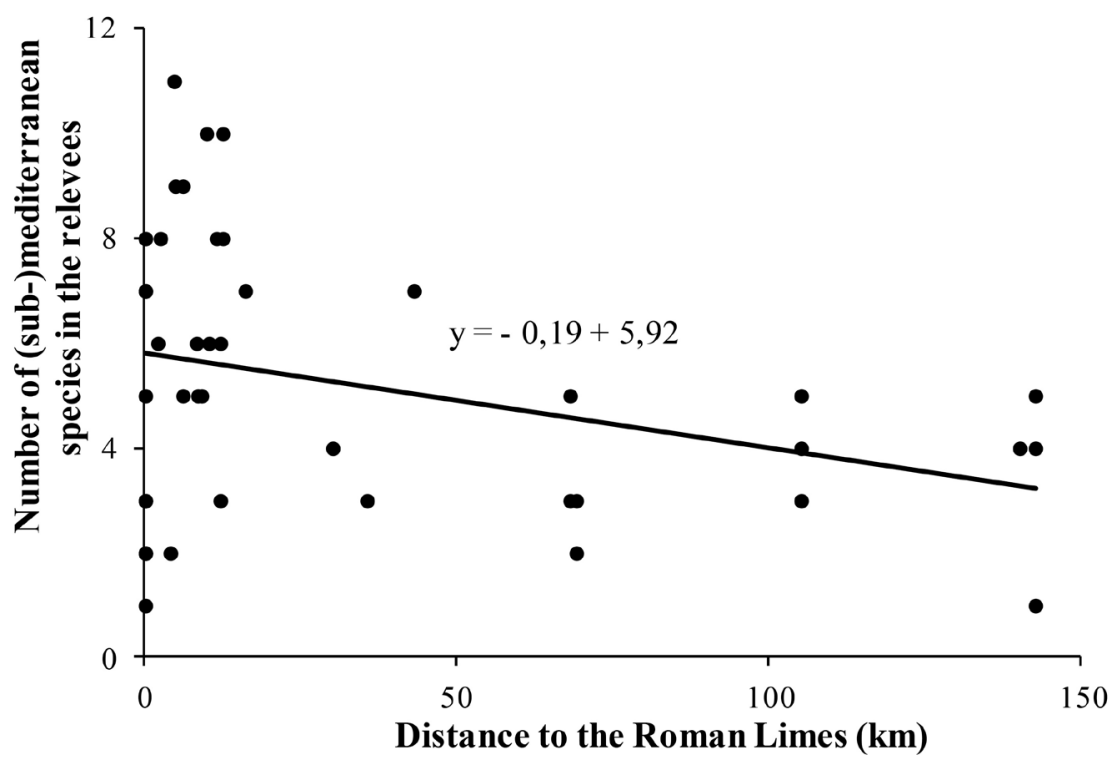

\section{The Migration period - a climate pessimum as catalyst}

plentiful occurrence of the pellitory-of-the-wall (Parietaria officinalis) in the floodplains of the Danube at Vienna is a relict of the Roman troops. If grassland species were intentionally introduced, we do not know. The pattern of a declining number of (sub-)Mediterranean species in calcareous grasslands of the Jurassic mountains within reasonable distance of the empire's limites, let us at least assume some impact (Figure 10; Baumann 2006; Poschlod, Baumann 2010).

Finally, for the supply of the Roman troops but also the increasing civil population, large forest areas were also cut (Figure 11; Küster 1994; Junkelmann 2006). The increasing demand for firewood in combination with coppicing led to the transformation of the beech forests to oak-hornbeam forests, the latter species being able to resprout after coppicing (Ellenberg 1996).
Another climate pessimum with lower mean annual temperatures, less precipitation and changeful weather (extreme weather events with flood disasters along the coast of the North Sea) started around 350 AD and lasted until 600 AD (Migration Period, early Medieval Age; Lamb 1995; Büntgen et al. 2011). The cause of this climate pessimum was probably low sun activity (Schreg 2010; Schreg, Sirocko 2010; Wirth et al. 2013). Reinforcing acted a dust veil in the upper atmosphere which reflected the sunlight and caused a global cooling down of the mean annual temperature of up to $3^{\circ} \mathrm{C}$, the strongest during the last 2000 years (Stothers 1984a; Larsen et al. 2008). The effects are particularly obvious for the period between 536 to $545 \mathrm{AD}$, manifested in the northern hemisphere through the increased

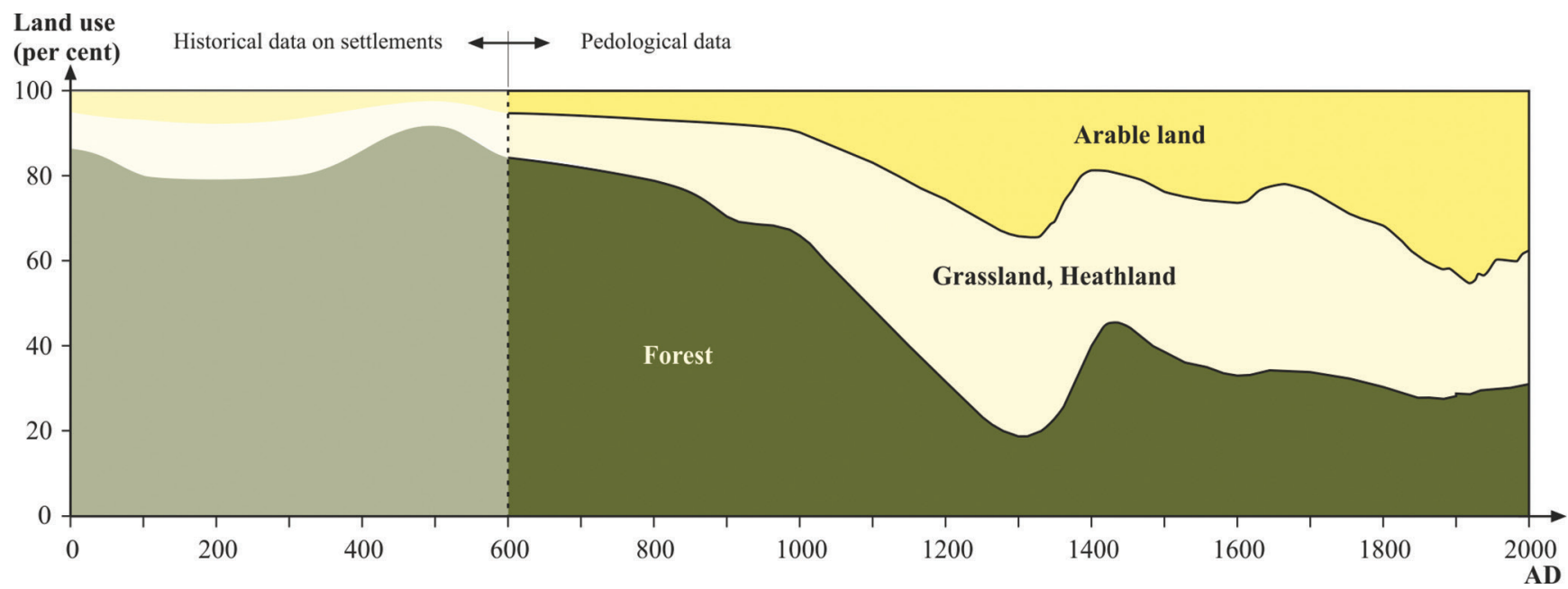

Figure 11. Chronological development of open man-made habitats and forests in the landscape of Germany since the beginning of the common era (after Bork 2006 and Poschlod 2015). 
sulphate depositions in Arctic ice cores (Larsen et al. 2008) and in the extremely narrow annual rings and frost rings in trees (Baillie 1994; D’Arrigo et al. 2001a; 2001b). Volcanic eruptions in the tropics have been suggested as the origin of the dust veil (Larsen et al. 2008; Ferris et al. 2011; if Ilopango, El Salvador: age dating 430 AD, Dull 2004; if Krakatau in southeast Asia: Keys 1999; if Rabau in Papua New Guinea: Stothers, Rampino 1983). However, much more likely is a comet impact (Baillie 2001; 2007; Rigby et al. 2004). Historical chronicles confirm a dust veil and subsequent famines and plague epidemics (Stothers and Rampino 1983; Rampino et al. 1988) for the $6^{\text {th }}$ century. The Byzantine historian Prokopius noted for 536/537 AD (Dewing 1916): "And it came about during this year that a most dread portent took place. For the sun gave forth its light without brightness, like the moon, during this whole year, and it seemed exceedingly like the sun in eclipse, for the beams it shed were not clear nor such as it is accustomed to shed. And from the time when this thing happened men were free neither from war nor pestilence nor any other thing leading to death. And it was the time when Justinian was in the tenth year of his reign." At the same time, other historical authors from Constantinople described the phenomenon, for example, Zachariah of Mytilene (" ... and the sun began to be darkened by day and the moon by night ..." and "... as the winter was a severe one, so much so that from the large and unwonted quantity of snow the birds perished ..."; Hamilton, Brooks 1899) and Johannes Lydus ("... if the sun becomes dim because the air is dense from rising moisture-as happened in the course of the recently passed fourteenth indiction (535/36) for nearly a whole year, ..., so that the produce was destroyed because of the bad timeit predicts heavy trouble in Europe. And this we have seen from the events themselves, when many wars broke out in the west"; Arjava 2005). Michael the Syrian probably quoting John of Ephesos wrote in the $12^{\text {th }}$ century of this period: “ ... there was a sign in the sun the like of which had never been seen and reported before in the world. If we had not found it recorded in the majority of proved and credible writings and confirmed by trustworthy people, we would not have recorded it; for it is difficult to conceive. So it is said that the sun became dark and its darkness lasted for one and a half years, that is, eighteen months. Each day it shone for about four hours, and still this light was only a feeble shadow. (...) The fruits did not ripen, and the wine tasted like sour grapes"; Arjava 2005).

And in Italy the Roman praetorian prefect Flavius Magnus Aurelius Cassiodorus wrote around 538 AD to the delegate Ambrosius: "The Sun, first of stars, seems to have lost his wonted light, and appears of a bluish colour. We marvel to see no shadows of our bodies at noon, to feel the mighty vigour of his heat wasted into feebleness, and the phenomena which accompany a transitory eclipse prolonged through a whole year. The Moon too, even when her orb is full, is empty of her natural splendour. Strange has been the course of the year thus far. We have had a winter without storms, a spring without mildness, and a summer without heat. Whence can we look for harvest, since the months which should have been maturing the corn have been chilled by Boreas?" (Hodgkin 1886).

In central Europe glaciers expanded (Holzhauser et al. 2005; Joerin et al. 2006). Whole tribes started to migrate from north to south and east to (south)west due to famine and restricted food supply. Drought periods in central Asia caused the movement of the Huns to central Europe (Blümel 2002). The vehemence of the migrations was one of the reasons of the breakdown of the Roman Empire (Heather 2005). Not only within but also outside the limites, this period is characterized through its increase of tree pollen and decrease of pollen from cereals and settlement indicators (Donat, Lange 1983; Küster 1988; Müller-Wille et al. 1988; Dörfler 1992; Dreßler et al. 2006; Hempel 2009; Schreg, Sirocko 2010).

Such changes in pollen indicate the abandonment of many settlements as well as their arable fields and grasslands (Figures 11) in which nearly no new species appeared during that period (Figures 6 to 8). At the beginning of the Medieval Age central Europe was therefore still strongly dominated by forests, which is also indicated in that aurochs and European bison were still present (Poschlod 2015).

\section{The medieval climate optimum - the expansion of man-made habitats and man-made landscapes}

From $850 \mathrm{AD}$ to around $1250 \mathrm{AD}$ there was another warming (medieval warm period or medieval climate anomaly; Figure 9; Lamb 1965; Le Roy Ladurie 1967; 2009b; 2009c; Hughes, Diaz 1994; Glaser 2008; Mann et al. 2008; Guiot et al. 2010; Ljungqvist 2010; Goosse et al. 2012a). Most publications and the changes in the man-made landscape give a clear picture of a warm period with temperatures compared to today or even higher for central Europe. Depending on the proxies used (annual rings, pollen, diatom, foraminifer analyses, etc.) temperatures have been reconstructed as being somewhat lower to around $2{ }^{\circ} \mathrm{C}$ higher compared to mean annual temperatures between 1961 to 1990 (Mann et al. 1999; Blümel 2002; 2006; Moberg et al. 2005; Loehle 2007; Glaser 2008). Dendroecological data allows us to assume that there was a temperature decrease between 1050 and 1150 (Büntgen et al. 2006; Corona et al. 2010), and some authors even state that there were only three short warmer periods (1010-1040, 1070-1105, 1155-1190; Crowley, Lowery 2000). The latest meta-analysis confirmed up to more than $2^{\circ} \mathrm{C}$ higher temperatures for Europe in the $10^{\text {th }}$ century, as well as at the end of the $12^{\text {th }}$ and beginning of the $13^{\text {th }}$ century (PAGES $2 \mathrm{k}$ Consortium 2013). However, a global warming probably did not take place (Bradley et al. 2003; Mann et al. 2009; PAGES 2k Consortium 2013).

Causes for the warming were an increased solar activity and radiation (Bard et al. 2000; Shindell et al. 2001; Muscheler et al. 2007; Guiot et al. 2010) that resulted in the dislocation of the Gulf Stream to the north (Goosse et al. 2012b). The solar activity probably fostered a positive North 


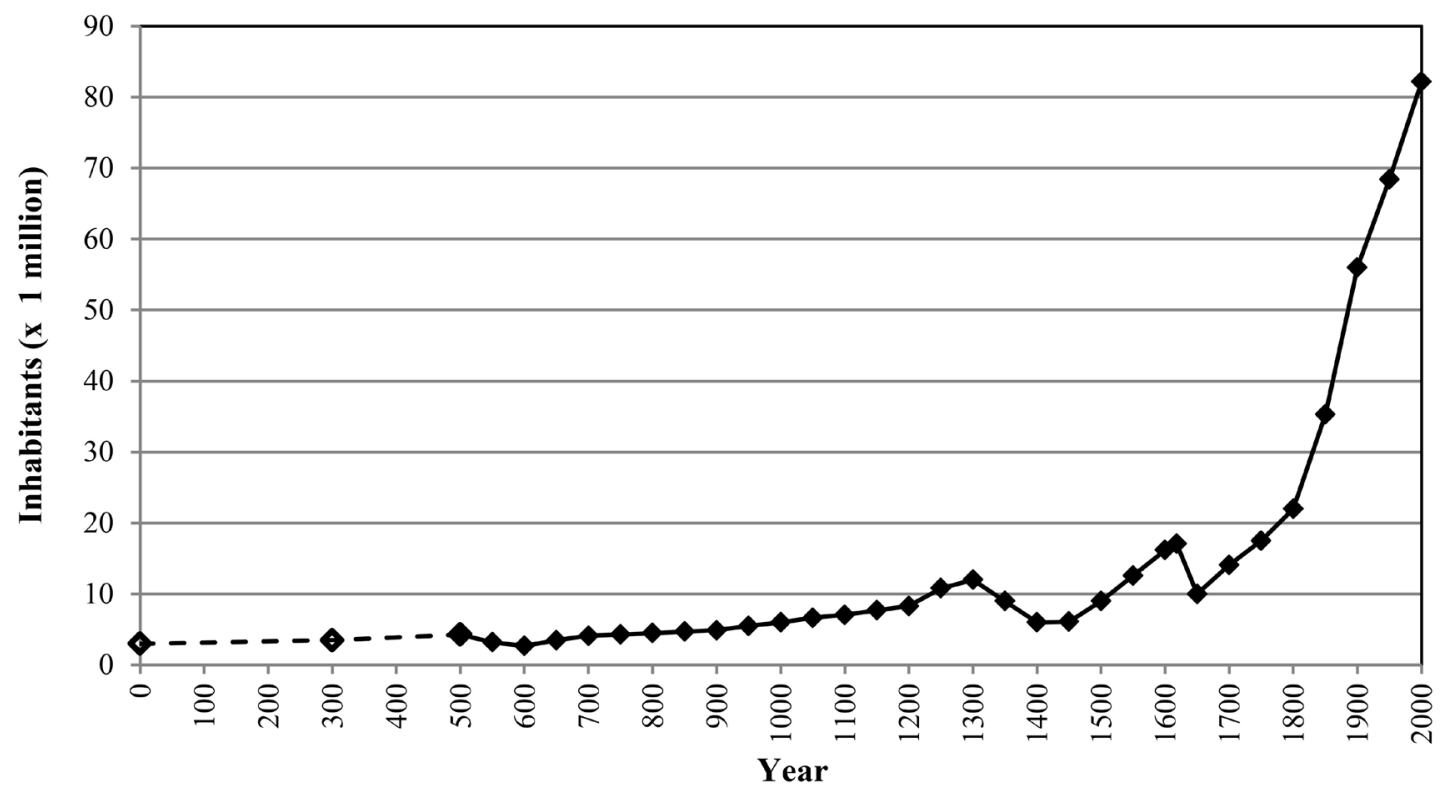

Figure 12. Chronological population development in Germany since the beginning of the common era (from Poschlod 2015).

Atlantic Oscillation (fluctuation of atmospheric pressure differences between the Iceland depression to the north and the Azores anticyclone to the south in the North Atlantic) which brought mild and moist air to central Europe (Trouet et al. 2009; van Loon et al. 2012).

The climate optimum allowed an increase in the human population which reached its highest density up until then (Figure 12; Grupe 1986). It resulted in the largest ever expansion of man-made landscape in central Europe (Figure 11; Bork et al. 1998; Bork 2006). This development is also reflected in the number of towns founded around then (Figure 13), reaching its peak in the $12^{\text {th }}$ and $13^{\text {th }}$ century (Stoob 1956). Accordingly, the number of villages also increased, mainly through the clearing of forests ("great age of clearing"; Smith 1978), especially in less favourable regions such as mountains (Fehn 1966, Smith 1978). Villages still existing in Germany from this period have names whose ending correspond to the kind of forest clearing (e.g. -reute, -scheid, -schlag, -rod from clearing through felling; and -brand, -schwend from clearing through burning), or

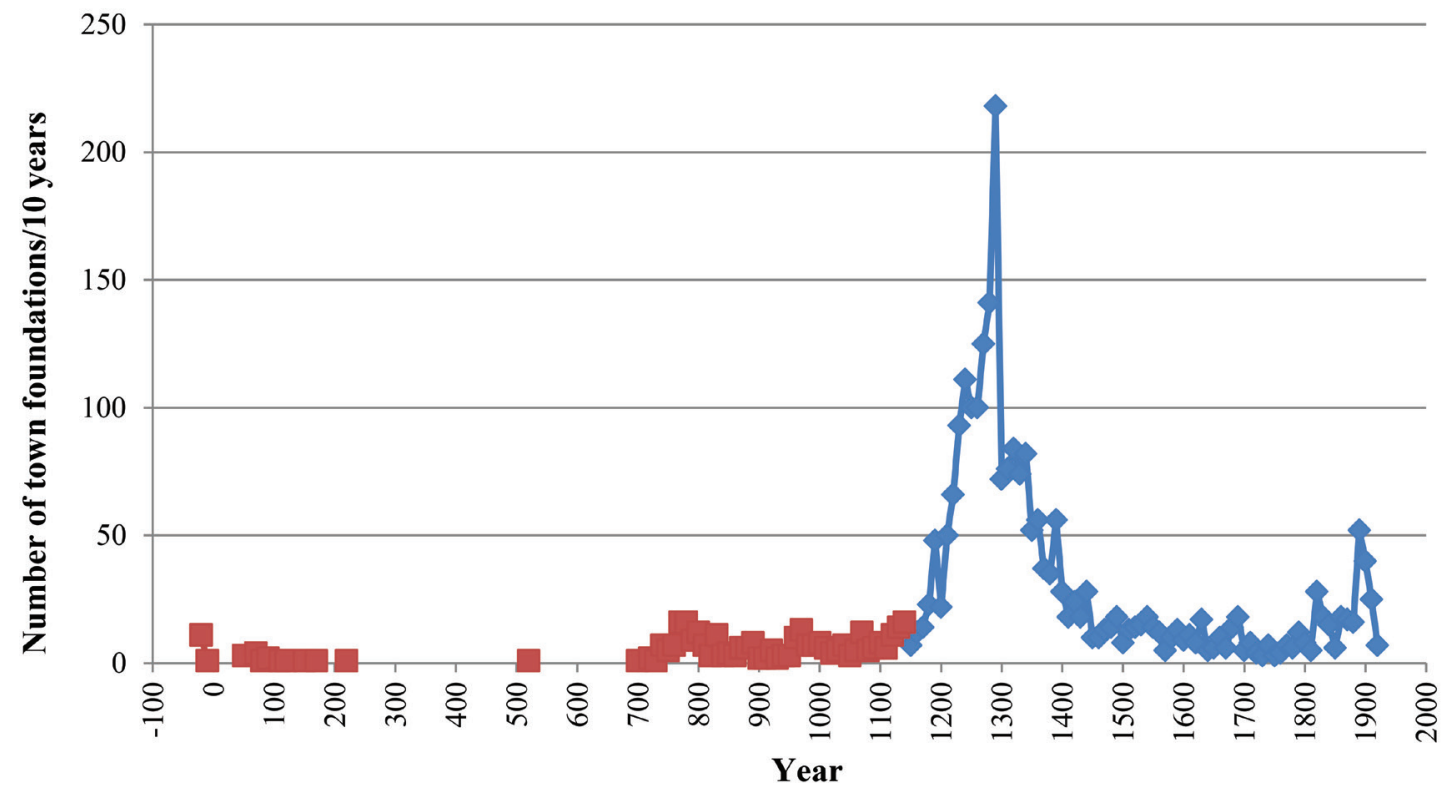

Figure 13. Chronological development of town foundations in Germany from $100 \mathrm{BC}$ to $1100 \mathrm{AD}$ (red squares) and in central Europe since $1100 \mathrm{AD}$ (blue squares; from Poschlod 2015). Data before 1150 from different sources; data ( $\mathrm{n}=\mathrm{ca} .2000)$ after 1150 from Stoob (1956). Definitions of towns according to different criteria such as privilege, fortification, economy, society and magisterial infrastructure (Haase 1958). 
according to their topography (-bach - brook; -tal - valley; -berg - mountain; Bach 1954). The Gothic architecture and style are considered the expression of a powerful, surplusgenerating society (Blümel 2002).

A perfect indicator for the medieval warming is viniculture (David-Sirocko, Sirocko 2010), which expanded during this period to England and the Baltic states (Weber 1980; Lamb 1995), even to regions where there was no viniculture possible in the $20^{\text {th }}$ century.

Many thermophilous horticultural and medical plants were introduced, mainly from the Mediterranean and West Asia, which included: wallflower (Erysimum cheiri), hyssop (Hyssopus officinalis), and catnip (Nepeta cataria; Lohmeyer, Sukopp 1992). Today they are naturalized in warm and dry habitats and act as a reminder of this warm period. From England, data on certain animals show how they had their most northern distribution during this period. One example is the Nettle Ground Bug (Heterogaster urticae), which occurred in the $20^{\text {th }}$ century only in southern England. It has been found in Roman and medieval deposits in York, in the north of England (Buckland 1986; Hall, Kenward 2004).

The population growth resulted not only in an expansion of arable fields and grasslands, particularly in the mountains, but also in an improvement of agricultural practices. Peatland cultivation started in northwest Germany (Berger 1950; Rabenstein 1982; Göttlich, Kuntze 1990; Behre 2008). Marshlands on the North Sea coast were colonised (Behre 2008).

In south and west Germany, as well as in Switzerland, France and Belgium, the three-field rotation system was already established by the early Medieval Age, whereas in the eastern part of central Europe the alternate arable-fieldgrassland use was still practiced (Smetánka 2009). The three-field rotation system resulted in a final differentiation of the arable field and grassland vegetation. In contrast, in northwest Germany and the Netherlands the one-field-system with its permanent rye cultivation was practiced (GringmuthDallmer 2003), which contributed to the strong expansion of heathlands due to the necessary regular fertilization through the "Plaggen" economy (Figure 4; Behre 2008).

Compared to the Roman Empire period, only a relatively few new crop plants were introduced: buckwheat (Fagopyrum esculentum), cowpea (Vigna unguiculata), common sorrel (Rumex acetosa), common salsify (Tragopogon porrifolius), parsnip (Pastinaca sativa), (wild) cabbage (Brassica oleracea), carrot (Daucus carota ssp. sativus), spinach (Spinacia oleraceae) and endive (Cichorium endivia), which were respectively used either as root or leafy vegetables, and tuber or salad plants (Poschlod 2015). The "agricultural heritage" of the Romans has determined the agriculture and habitats that have evolved from the respective practices in central Europe up until Modern Times (Poschlod 2015).

From original documents we know about the grassland use of peatlands, which date back to the $11^{\text {th }}$ and $12^{\text {th }}$ century (e.g. "Pfrunger Ried" in Upper Swabia; Göttlich, Kuntze 1990). Peatlands were grazed and used for fodder and dung production. The latter was used to fertilize the arable fields that were created during peatland amelioration; from that time on until the $20^{\text {th }}$ century, in German, the word existed "the meadow is the mother of the arable field" (Brüne 1946; Göttlich, Kuntze 1990). With the fodder production the first wet meadows in peatlands may have developed.

In northwest Germany, the first settlements at the edge of the geest (sandy heathland) were founded to cultivate the minerogenous mires. They stemmed from the foundation of Cistercian monasteries (e.g. Loccum 1163, Osterholz 1185, Wienhausen around 1225, Hude 1232, Lilienthal 1232, and Scharnebeck at Lüneburg 1243, etc.; Wegener 1985; Eberl 2002). In $1300 \mathrm{AD}$, the complete connected network of dykes of Friesia was finished (Behre 2008). Since that time freshwater and saltwater habitats have been separated and the ecologically diverse transition zone (brackish water) has been lost (Behre 2008).

The food shortage due to the bulging population caused the re-introduction, or increase, of archaic land-use types such as the alternate arable-field-grassland-coppice use which was particularly practiced in mountain areas such as the Bavarian Forest, the Black Forest, the Eifel, the Siegerland and the Spessart (Poschlod 2015; see also Rösch 1990; Lüning 2000). Since the different land use practices were applied at one locality at the same time but on different parcels of land, an extremely high biodiversity began to develop in these regions. The open structure of the coppices allowed the strong expansion of certain species, such as ground-living birds like the hazel grouse (Tetrastes bonasia; Poschlod 2015). Another land-use practice, ridge and furrow, dates from this period of man-made landscape expansion (Schenk 2000).

Due to the increased livestock, extensive hay production was practiced, resulting in the first expansion of meadows. That meadow-use was only practiced on a larger scale in the Medieval Age, is also supported through the fact that the German word for meadow, "Wiese", does not stem from the Latin "pratum" like e.g. the French word "pré" but first appears at the end of the $8^{\text {th }}$ century. The etymological origin is found in the old nordic word "veisa" (mud) or the AngloSaxon terms "wâs" (moisture) and "wase" (swamp) (Grimm, Grimm 1854-1960; Boesch 1981). In the German dictionary, Grimm, Grimm (1854-1960) wrote that the term moisture seems to be strongly attached to the word "Wiese" and that the original meaning "swampy grassland" has been lost today. Konold (1994) even assumes that the prototype of the meadow was an irrigated meadow. It can thus be concluded that the first meadows were mainly established in river floodplains, which is confirmed through the frequent arachaeobotanical findings of wet meadow plants, such as Ragged Robin (Lychnis flos-cuculi), meadowsweet (Filipendula ulmaria), common spike-rush (Eleocharis palustris) and wood clubrush (Scirpus sylvaticus; Willerding 1996). However, the practice of meadow irrigation was already described by Columella in the $1^{\text {st }}$ century AD (Richter 1981).

In central Europe, especially in the foothills of the Alps and in southern Scandinavia, hay was produced in wooded meadows (Swiss “Studmatten”, Burger 1927; swedish "(löv) ängar"; Hæggström 1995; Emanuelsson 2005), which is 
another ancient meadow type. The wooded meadows were a multi-functional habitat: trees were used for lumber (oak), firewood (birch, etc.), fertilizer (ash of the leaves of the common hazelnut), fruit (hazelnut, rowan berries) or leaf hay production (ash, lime tree, etc.), with the grassland underneath mown and later grazed (Kukk, Kull 1997; Hæggström 1998; Emanuelsson 2009). The oaks were also maintained to provide acorns (mast) for pig fattening in autumn (Backmund 1941).

Finally, the first artificial ponds were constructed - another new man-made habitat which has developed its own species assembly due to its specific management practices (Poschlod 2015).

According to Bork et al. (1998; see also Bork 2006), the proportion of forest decreased to less than $20 \%$ whereas the proportion of arable fields increased to over 30\% and that of meadows, pastures and heathlands to around 50\% (Figure 11). At the end of the $13^{\text {th }}$ century there was the largest expansion of habitat from man-made landscape ever (until today). Relicts of that period, such as clearance cairns which were piled up at the edge of arable fields during that period, can still be found in forests in mountain areas today, often covered by shrubs and trees (Poschlod 2015).

\section{The Little Ice Age - extreme weather events initiate a climate pessimum at the end of the Medieval period and the beginning of Modern Times}

At the beginning of the $14^{\text {th }}$ century the last climate pessimum began; it started with a period of extreme weather events. At the beginning of Modern Times, from the mid- $16^{\text {th }}$ century until the beginning of the $19^{\text {th }}$, a period of lower mean annual temperatures and fluctuating precipitation ensued (Le Roy Ladurie 2004; 2009a; 2009b; Glaser 2008). Due to the cooler temperatures this period has been called the "Little Ice Age" (Le Roy Ladurie 2004; Glaser 2008).

Its causes might have been fluctuations in solar activity, which decreased at the end of the $14^{\text {th }}$ century and reached other minima in the $16^{\text {th }}$ and $17^{\text {th }}$ century (Lean 2002; Shindell et al. 2003; Solanki et al. 2004; Steinhilber et al. 2008; see also Vonmoos et al. 2006). The period, however, was also characterized by some strong volcanic eruptions on Vanuatu in the $13^{\text {th }}$ and $15^{\text {th }}$ century and Papua New Guinea in the $16^{\text {th }}$ and $17^{\text {th }}$ century (Cowie 2007; Miller et al. 2012; see also Shindell et al. 2003).

As examples of the extreme weather events of the $14^{\text {th }}$ century, the period from 1311 to $1319 \mathrm{AD}$, as well as the year of the millenium floods, $1342 \mathrm{AD}$, should be mentioned. Between 1311 and 1319, heavy precipitation flooded large parts of the central European landscape, severely damaging crop harvests. In the chronicle of Bad Windsheim (Bavaria) it was written for 1315 that the wet summer had caused a big famine which forced people to eat dogs, horses - and even thieves who had been hanged (Glaser 2008)!

The following Latin poem from this year describes the situation: "Ut lateat nullum tempus Famis, ecce CVCVLLVM
Albani festa de narvant tristia gesta, Terxam portentis tetigit manus Omnipotentis, Imbribus in numeris, merguntur senina qua vis, Brutaque cum stabulis pereunt, atque oppida villis." CVCVLLVM on the one hand, relates to the year 1315, and, on the other hand, to the cuckoo which was in Germany a synonym for the devil ("geh zum Kuckuck", "der Kuckuck soll dich holen" which means "go to hell"). In the vicinity of settlements the cuckoo was a bringer of woe (BächtoldStäubli, Hoffmann-Krayer 1927-1942). Translated the poem means: „That the hunger is not hidden at any time, look at the cuckoo, it tells about sad incidents at the feast of Saint Alban, the hand of the Almighty has touched the earth with awful auguries, the sowings cease to exist through countless rainfalls, the livestock perish together with the stables and the towns and the villages".

Continuous tallies of the medieval grain harvest (from 1211 to 1491) in England showed indeed only half of the usual yield for 1315 (Grove 2002; Campbell, Ó Gráda 2011).

The year 1342 was that of the thousand-year flood (Glaser 2008). Many reports can be found in chronicles throughout central Europe, for example, from Erfurt (Thuringia; according to Weikinn 1958 from Tetzlaff et al. 2002; Glaser 2008): "This summer there was a such large flood which did not develop from rainfalls but it seemed if the water sputtered from everywhere, even from the peaks of the mountains ... and over the walls of Cologne one could run over with barges ... Danube, Rhine and Main ... carried towers, solid walls and houses away ... as well as the ramparts of towns ... and the watergates of the sky were open, and rain fell on the earth like in the $600^{\text {th }}$ year of Noahs life, ... it happened in Würzburg that the Main destroyed the bridge with strong force and forced many people to leave their housings ...". Flood events also occurred in the northwestern and northern parts of central Europe, such as the Rhine-Meuse-Scheldt delta where the dykes broke, and the valleys of Elbe, Eider and Weser (Arends 1833).

The effects on the man-made landscape were tremendous. Due to the low proportion of forest and large expansion in arable field area, more than $50 \%$ of the soil eroded during the last 2000 years was washed away, in just the year 1342 alone at least 20\% (Bork et al. 1998; Bork 2006). Alluvial clay deposits up to several metres in height reshaped floodplains during this period (Mensching 1951; Händel 1967; Bork et al. 1998; Dotterweich 2008; Stolz, Grunert 2008; Hempel 2009).

Whole new habitats developed. Since proportions of forest cover were low, potential rainfall interception was greatly reduced, with the result that most of the precipitation seeped into the soil, increasing percolation and spring water emersions. As a consequence, many swampy hillsides underwent paludification and sloping mires started to be formed. In fact, the origin of many sloping mires started during the Medieval Age (Lange et al. 1978; Jeschke 1990; see also Succow, Jeschke 1986; Kapfer, Poschlod 1997). Also the development of many "Missen" mires in the higher reaches of the Black Forest started during this period (Radke 1973). Many plants and animals characteristic for wetlands 
or mires might have therefore expanded their distribution within this century.

Extreme weather events also reshaped the coast of the North Sea. The second Marcellus flood in 1362, also called the "Grote Mandrenke" (great drowning of men), was able to give the German and Dutch coast its present-day shape (Petersen, Rohde 1977; Behre 2008).

Heavy damages through pathogens and harmful insects followed the periods of extreme weather events. During 1338, 1339 and 1340, plagues of migrating locusts occurred over a vast region from Bohemia and Austria to Bavaria, Thuringia and Hesse (Glaser 2008).

The landscape, however, was not only reshaped by floods and soil erosion, but also through a large increase in forest area (Figure 11). Due to the many failures of crops, people suffering from famines were more prone to illness. The subsequent epidemics, such as the Black Death, caused a catastrophic decrease in population - from around 12 to 6 million people in Germany for instance (Figure 12) - and thus the abandonment of settlements and man-made habitats such as arable fields and grasslands. According to Abel (1978), the number of settlements in Germany decreased from 170,000 to 130,000 . In certain regions, such as Hesse, the proportion of abandoned settlements was around 50\%. In mountain areas, such as the Rhön or Solling, it could have even reached $70 \%$ (Born, Haarberg 1963; Abel 1976; 1978; Born 1984). This period is also called the medieval period of deserted settlements (Abel 1978). Relicts from this period include the "ridge and furrow" of abandoned field systems, which are found today under the forests of mountain areas where settlements had been founded just 100 to 200 years before. These relatively new settlements were the first to be abandoned.

The effect on species diversity has not yet been verified, but the process of abandonment contributed to the expansion of sheep husbandry by the local nobility. They wanted to maintain the landscape open - and thus added to the expansion of dry calcareous and sandy grasslands, as well as heathlands, in the landscape (Hornberger 1959; Poschlod, WallisDeVries 2002). During this period large-scale transhumance developed in south Germany (Poschlod, WallisDeVries 2002).

Furthermore, the following period of cooler temperatures at the end of the Medieval Age and the beginning of Modern Times may have accelerated various agricultural innovations. In the $16^{\text {th }}$ and $17^{\text {th }}$ centuries, when the famous winter paintings by Dutch and Flemish masters were produced, the improved three-field-rotation system and crop rotation with row crops were introduced to central Europe (Poschlod 2015). The improved field-rotation system meant that the fallow of the former traditional field-rotation system was given up and forage plants cultivated. These were red clover (Trifolium pratense), lucerne (Medicago sativa), common sainfoin (Onobrychis viciifolia) and crown vetch (Securigera varia). Many of these arable fields were later transformed into grasslands by natural succession and grazing, or hayseed application, where the three latter species often still occur today - as indicators of the former arable field use (Poschlod et al. 2008; Karlik, Poschlod 2009).
Row crops such as fodder beet and potato became an inherent part of crop rotation and resulted in the origin of new arable weed communities (phytosociological class of Chenopodietea; Ellenberg 1996; Hempel 2009). Through the introduction of false oat-grass (Arrhenatherum elatius var. elatius) at the end of the $17^{\text {th }}$, and start of the $18^{\text {th }}$ century from France, thus also called in German French rye grass, the socalled Arrhenatherum elatius meadows (Arrhenatheretum; Poschlod et al. 2009a, 2009b) developed. They were the dominant farm-meadow types up until the second half of the $20^{\text {th }}$ century (Ellenberg 1996).

The Little Ice Age lasted until the $19^{\text {th }}$ century. The coldest period was between 1805 and 1820. 1815 and the following years were probably the second coldest period after the event of $536 \mathrm{AD}$. Three large volcano eruptions were the cause for the dramatic cooling - the Soufrière on Saint Vincent in the Carribean erupted in 1812, the Mayon on the Philippines followed in 1814, and finally in 1815 the Tambora in Indonesia (Fagan 2000). The eruption of the Tambora, which started in April 1815, resulted in the most extreme cooling which lasted for at least three years (Stommel, Stommel 1983; Harington 1992; de Boer, Sanders 2004). The eruption is presumed to be the second largest (after the one in 1259 which has not yet been localised) of the more than 5500 until-now dated volcano eruptions (Stommel, Stommel 1983; Zielinski et al. 1994; Zielinski 2000). The year 1816 was in Europe (but also in North America) the "year without summer" (Stommel, Stommel 1983; Stothers 1984b). In Germany, the year got the name "eighteenhundred and frozen to death" (Hamm 1956). Mean annual temperatures decreased by more than $2{ }^{\circ} \mathrm{C}$ (Luterbacher et al. 2004). The consequences were crop failures and famines, especially in the south German and alpine regions (Fischer 1999; Specker 1993; 1995). During these years, anything eatable was eaten: hay was cooked, snails and slugs and even cats eaten (Scheitlin 1820). In a painting of 1817, people are pictured even grazing (Specker 1993; 1995)! The botanist and physician Heinrich Rudolf Schinz wrote a pamphlet on behalf of the agricultural commission of the Society for Natural History in Zurich, in which he described the usefulness and risk of alternative nutrition: "... for the benefit and protection of harm ... because the hunger does not select the best ..." (Specker 1995). In doing so, Schinz, when describing edible roots, particularly indicated the bulbs of marsh-orchids and gave advice to only eat them boiled: "If you would add some salt, pepper, caraway, sage, thyme, marjoram, mint, garlic, onions or chive, the simple dish would be more healthy and pleasant" (Specker 1995). Among the fleshy-fruity species, he recommended amongst others the berries of common whitebeam (Sorbus aria agg.) and rowan (Sorbus aucuparia agg.), as well as rose hips. Other herbs which were strongly collected during those years were common nettle (Urtica dioica) and common sorrel (Rumex acetosa). Even lower plants such as lichens were eaten (e.g. Iceland moss, Cetraria islandica; Fagan 2000). However, despite this heavy pressure on habitats and biodiversity, no detailed 
natural history data from that period exist. After this period, the Little Ice Age ended. However, already since the end of the $18^{\text {th }}$, beginning of the $19^{\text {th }}$ century, climate was no longer the main driving force affecting landscape, habitat and species diversity but human spirit, technical innovations, economic changes and political directives (Poschlod 2015). Only since very recently has the man-made climate change started to affect our landscape, habitat and species diversity again to such an extent.

\section{The recent climate change and the effects of climate regulating laws such as the EEG}

In contrast to former climate changes the most recent one is man-made, but just as before this one is also causing changes in the landscape, habitat and species diversity. One fact is that certain aquatic species, which we know through the analysis of macrorests in sediment deposits were more northernly distributed during the climate optimum of the Atlantic period or Neolithic Age, have started to spread again; this is known, for example, for Najas marina s.l. (Figure 2; Poschlod 2015). Continuous distribution mapping of other organisms since the $20^{\text {th }}$ century has shown the expansion in distribution of another plant, Ilex aquifolium, to the north, but more especially in many mobile organisms such as birds, locusts, beetles, dragonflies, butterflies and wild bees (Poschlod 2015).

Political efforts as a reaction to this climate warming, such as the implementation of directives or laws to decrease the consumption of fossil resources, have a much stronger effect on landscape and habitat diversity changes. In Germany this is especially true for the law of renewable resources (EEG Erneuerbare Energien-Gesetz), which was implemented in the year 2000. It has resulted in an increase of area under cultivation for corn (Zea mays) from 15,000 to 25,000 $\mathrm{km}^{2}$ to produce biogas. Additionally, rape (Brassica napus subsp. napus) is cultivated on another $9130 \mathrm{~km}^{2}$ to produce biodiesel, and sugar beet and wheat on another $2,500 \mathrm{~km}^{2}$ for bioethanol. In total, more than $20,000 \mathrm{~km}^{2}$ of arable land in Germany are under cultivation for the production of biofuels: this is nearly $20 \%$ of the total arable land! The high input of fertilizers and pesticides has strongly decreased biodiversity and, via atmospheric deposition, is even changing other habitats such as the last remaining natural peatlands - and thus similarly decreasing species diversity (Poschlod 2015). The EEG also supports the establishment of solar panel parks and wind farms; the numbers are continuously increasing. Presently there are around 25,000 inland wind turbines. Detailed data on the numbers and sizes of solar panel parks in the open landscape are not even available (Poschlod 2015)! The future dimension of the actual climate change and its effect on landscape, habitat and species diversity is not yet clear. However, the EEG as a reaction to the actual climate change has resulted in a dramatic decline of speciesrich grasslands, one of our most diverse habitats and diverse cultural heritage (Poschlod 2014).

\section{Conclusion}

It has been shown that climate and climate change have been, and still are, important drivers of our man-made landscape, its habitats and species diversity. Climate optima were shown to have been important for an increase in both habitat and species diversity. Therefore, actual climate change may be also a chance - if we take the past into account. Migrations during climate optima (but also pessima) may have had another strong effect on our biodiversity. However, we have to take into account that only very specific landuse practices have created and maintained our biodiversity. To save and to maintain biodiversity we have to understand the historical and actual context (Poschlod 2014; 2015). This challenge can only be handled in the context of broader interdisciplinary and transdisciplinary cooperation of the respective disciplines than that existing until now.

\section{Acknowledgements}

I thank Jaromír Beneš and PAPAVER for the invitation to the $11^{\text {th }}$ Conference on Environmental Archaeology and to the PAPAVER seminar "Driving forces of the history of the central European/German man-made landscape and selected habitats" which brought me to elaborate my presentations to this review. Special thanks go to Sabine Fischer for drawing the maps, two anonymous referees for their comments and to Steven Ridgill for the correction of the linguistic style of the manuscript.

\section{References}

ABEL, W. 1976: Die Wüstungen des ausgehenden Mittelalters. Third ed. Gustav Fischer, Stuttgart.

ABEL, W. 1978: Geschichte der deutschen Landwirtschaft vom frühen Mittelalter bis zum 19. Jahrhundert (Deutsche Agrargeschichte II). Third ed. Eugen Ulmer, Stuttgart.

ABRAMS, M.D. 1992. Fire and the development of oak forests. BioScience 42, 346-353.

AKADEMIE FÜR RAUMFORSCHUNG UND LANDESPLANUNG, BEHRMANN, W. 1962: Deutscher Planungsatlas Band IX. Atlas von Berlin. Gebrüder Jänecke, Hannover.

AKERETT, Ö., JACOMET, S. 1997: Analysis of plant macrofossils in goat/ sheep faeces from the Neolithic lake shore settlement of Horgen Scheller - an indication of prehistoric transhumance? Vegetation History and Archaeobotany 6, 235-239.

AKERET, Ö., HAAS, J.N., LEUZINGER, U., JACOMET, S. 1999: Plant macrofossils and pollen in goat/sheep faeces from the Neolithic lakeshore settlement Arbon Bleiche 3, Switzerland. The Holocene 9, 175-182.

ALLEY, R. B., MAYEWSKI, P. A., SOWERS, T., STUIVER, M., TAYLOR, K. C., CLARK, P. U. 1997: Holocene climatic instability: A prominent, widespread event 8200 yr ago. Geology 25(6), 483-486.

AMESBURY, M.J., CHARMAN, D.J., FYFE, R.M., LANGDON, P.G., WEST, S. 2008: Bronze Age upland settlement decline in southwest England: testing the climate change hypothesis. Journal of Archaeological Science 35, 87-98.

ANTHELME F., MICHALET R., BARBARO, L., BRUN, J.-J. 2003: Environmental and spatial influences of shrub cover (Alnus viridis DC.) on vegetation diversity at the upper treeline in the inner western Alps. Arctic Antarctic and Alpine Research 35, 48-55. 
ARENDS, F. 1833: Physische Geschichte der Nordsee-Küste und deren Veränderungen durch Sturmfluthen seit der Cymbrischen Fluth bis jetzt. Zweiter Band. H. Woortman jun., Emden.

ARJAVA, A. 2005: The Mystery Cloud of 536 CE in the Mediterranean. Dumbarton Oaks Papers 59, 73-94.

ASH, H.B. 1941: Columella. On Agriculture. Volume I: Books 1-4. Loeb Classical Library 361. Harvard University Press, Cambridge MA.

BACH, A. 1954: Deutsche Namenkunde. Band II, 2. Die deutschen Ortsnamen. Carl Winter, Heidelberg.

BÄCHTOLD-STÄUBLI，H., HOFFMANN-KRAYER，E. 1927-1942: Handwörterbuch des deutschen Aberglaubens. 10 volumes. De Gruyter, Berlin.

BACKMUND, F. 1941: Der Wandel des Waldes im Alpenvorland. Eine forstgeschichtliche Untersuchung. Schriftenreihe Akademie Deutsche Forstwirtschaft 4, 1-126.

BAHR, A., ARZ, H.W., LAMY, F., WEFER, G. 2006: Late glacial to Holocene paleoenvironmental evolution of the Black Sea, reconstructed with stable oxygen isotope records obtained on ostracod shells. Earth and Planetary Science Letters 241, 863-875.

BAILLIE, M. 1994: Dendrochronology raises questions about the nature of the AD 536 dust-veil event. The Holocene 4, 212-217.

BAILLIE, M. 2001: The AD 540 event. Current Archaeology 15, 266-269.

BAILLIE, M. 2007: The case for significant numbers of extraterrestrial impacts through the late Holocene. Journal of Quaternary Science 22, 101-109.

BAKER, A., SMART, P.L., BARNES, W.L., EDWARDS, R.L., FARRANT, A. 1995: The Hekla 3 volcanic eruption recorded in a Scottish speleothem? The Holocene 5, 336-342.

BALON, E.K. 1995: Origin and domestication of the wild carp, Cyprinus carpio: from Roman gourmets to the swimming flowers. Aquaculture 129, 3-48.

BARD, E., RAISBECK, G., YIOU, F., JOUZEL, J. 2000: Solar irradiance during the last 1200 years based on cosmogenic nuclides. Tellus 52B, 985-992.

BARONI, C., OROMBELLI, G. 1996: The Alpine "Iceman" and Holocene Climatic Change. Quaternary Research 46, 78-83.

BAR-YOSEF, O. 1998: The Natufian Culture in the Levant, Threshold to the Origins of Agriculture. Evolutionary Anthropology 6, 159-177.

BAUMANN, A. 2006: On the vegetation history of calcareous grasslands in the Franconian Jura (Germany) since the Bronze Age. Dissertationes Botanicae 404, 1-194.

BEHRE, K.-E. 2008: Landschaftsgeschichte Norddeutschlands. Umwelt und Siedlung von der Steinzeit bis zur Gegenwart. Wachholtz, Neumünster.

BEHRINGER, W. 2007: Kulturgeschichte des Klimas. Von der Eiszeit bis zur globalen Erwärmung. Second ed. C. H. Beck, München.

BERGER, H. 1950: Der Regierungsbezirk Stade - Das Teufelsmoor Schriftenreihe des Informationsdienstes der Regierung in Stade 10, 2-15.

BERGER, J.-F., GUILAINE, J. 2008: The 8200 cal BP abrupt environmental change and the Neolithic transition: a Mediterranean perspective. Quaternary International 200, 31-49.

BINFORD, L. R. 2001: Constructing frames of reference: an analytical method for archaeological theory building using ethnographic and environmental data sets. University of California Press, Berkeley.

BIRKS, H. J. B. 2003: Quantitative palaeoenvironmental reconstructions from Holocene biological data. In: Mackay, A., Battarbee, R., Birks, J., Oldfield, F. (Eds.): Global Change in the Holocene. Arnold, London, 107-123.

BIRLEY, A. R. 1999: Tacitus. Agricola and Germany. Oxford University Press, Oxford, New York.

BLEICHER, N., SIROCKO, F. 2010: Weiträumiger Kulturwandel am Beginn der einsetzenden Abkühlungen Mitteleuropas. In: Sirocko, F. (Ed.): Wetter, Klima, Menschheitsentwicklung. Von der Eiszeit bis ins 21. Jahrhundert. Second ed. Wissenschaftliche Buchgesellschaft, Darmstadt, 119-123.

BLÜMEL, W. D. 2002: 20000 Jahre Klimawandel und Kulturgeschichte - Von der Eiszeit in die Gegenwart. In: Universität Stuttgart (Ed.): Wechselwirkungen - Jahrbuch aus Lehre und Forschung der Universität Stuttgart. Universität Stuttgart, Stuttgart, 2-19.

BLÜMEL, W. D. 2006: Klimafluktutationen - Determinanten für die Kultur- und Siedlungsgeschichte? Nova Acta Leopoldina NF 94, 346, 13-36.
BOESCH, B. 1981: „Matte“ und „Wiese“ in den alemannischen Urkunden des 13. Jahrhunderts. Beiträge zur Namenforschung, N.F. Beiheft 20, $1-10$

BOGAARD, A. 2002: Questioning the relevance of shifting cultivation to Neolithic farming in the loess belt of Europe: evidence from the Hambach Forest experiment. Vegetation History and Archaeobotany 11, 155-168.

BOGAARD, A. 2004: Neolithic farming in Central Europe. An archaeobotanical study of crop husbandry practices. Routledge, London, New York.

BORK, H.-R. (Ed.) 2006: Landschaften der Erde unter dem Einfluss des Menschen. Wissenschaftliche Buchgesellschaft, Darmstadt.

BORK, H.-R., BORK, H., DALCHOW, C., FAUST, B., PIORR, H.-P., SCHATZ, T. 1998: Landschaftsentwicklung in Mitteleuropa: Wirkung des Menschen auf Landschaften. Klett-Verlag, Stuttgart.

BORN, M. 1984: Wüstungskarten. In: Schwind, F. (Ed.): Geschichtlicher Atlas: Text- und Erläuterungsband. Hessisches Landesamt für geschichtliche Landeskunde, Marburg, 305-308.

BORN, M., HAARBERG, B. 1963: Wüstungen und heutige Siedlungen, Nördliches Hessen (Forschungsstand 1960). In: Stengel, E. E., Uhlhorn, F. (Eds.): Geschichtlicher Atlas von Hessen. Hessisches Landesamt für geschichtliche Landeskunde, Marburg, Karte 39a.

BOS, J. A. A., URZ, R. 2003: Late Glacial and early Holocene environment in the middle Lahn river valley (Hessen, central-west Germany) and the local impact of early Mesolithic people - pollen and macrofossil evidence. Vegetation History and Archaeobotany 12, 19-36.

BRADLEY, R.S., HUGHES, M. K., DIAZ, H. F. 2003: Climate in Medieval time. Science 302, 404-405.

BRAMANTI, B., THOMAS, M. G., HAAK, W., UNTERLAENDER, M., JORES, P., TAMBETS, K., ANTANAITIS-JACOBS, I., HAIDLE, M. N., JANKAUSKAS, R., KIND, C. J., LUETH, F., TERBERGER, T., HILlER, J., MATSUMURA, S., FORSTER, P., BURGER, J. 2009: Genetic discontinuity between local hunter-gatherers and central Europe's first farmers. Science 326, 137-140.

BRATHER, S. 2008: Archäologie der westlichen Slawen. Second ed. De Gruyter, Berlin.

BRÜNE, F. 1946: Zeitgemäße Düngungsfragen der Moorkultur. Zeitschrift für Pflanzenernährung, Düngung, Bodenkunde 37, 135-140.

BUCKLAND, P.C. 1986: An Insect Fauna from a Roman Well at Empingham, Rutland. Transactions of the Leicestireshire Archaeological Society 60, 1-6.

BÜNTGEN, U., FRANK, D. C., NIEVERGELT, D., ESPER, J. 2006 Summer temperature variations in the European Alps, A.D. 755-2004. Journal of Climate 19, 5606-5623.

BÜNTGEN, U., TEGEL, W., NICOLUSSI, K., MCCORMICK, M., TROUET, V., KAPLAN, J.O., HERZIG, F., HEUSSNER, K.-U., WANNER, H., LUTERBACHER, J., ESPER, J. 2011: 2500 Years of European Climate Variability and Human Susceptibility. Science 331, 578-582.

BURGER, H. 1927: Wytweiden und Studmatten. Schweizerische Zeitschrift für Forstwesen 78, 366-370.

BUSH, M. B. 1993: An 11400 year paleoecological history of a British chalk grassland. Journal of Vegetation Science 4, 47-66.

BYLEBYL, K., POSCHLOD, P., REISCH, C. 2008: Genetic variation of Eryngium campestre L. (Apiaceae) in Central Europe. Molecular Ecology 17, 3379-3388.

CAMPBELL, B. M. S., Ó GRÁDA, C. 2011: Harvest shortfalls, grain prices, and famines in preindustrial England. The Journal of Economic History 71, 859-886.

CAUVIN, J. 2000: The birth of the gods and the origins of agriculture. Cambridge University Press, Cambridge.

CLARE, L., JÖRIS, O., WENINGER, B. 2010: Der Übergang vom Spätneolithikum zur frühen Kupferzeit in Westasien um 8200 cal BP eine ethnoarchäologische Betrachtung. In: Gronenborn, D., Petrasch, J. (Eds.): Die Neolithisierung Mitteleuropas (The Spread of the Neolithic to Central Europe). Verlag des Römisch-Germanischen Zentralmuseums, Mainz, 45-60.

CLARK, J. S., MERKT, J., MULLER, H. 1989: Post-glacial fire, vegetation, and human history on the northern Alpine forelands, south-western Germany. Journal of Ecology 77, 897-925.

COHEN, M. 1977: The food crisis in prehistory: overpopulation and the origins of agriculture. Yale University Press, New Haven. 
CORONA, C., GUIOT, J., EDOUARD, J. L., CHALIÉ, F., BÜNTGEN, U., NOLA, P., URBINATI, C. 2010: Millennium-long summer temperature variations in the European Alps as reconstructed from tree rings. Climate of the Past 6, 379-400.

COUWENBERG, J., DE KLERK, P., ENDTMANN, E., JOOSTEN, H., MICHAELIS, D. 2001: Hydrogenetische Moortypen in der Zeit - eine Zusammenschau. In: Succow, M., Joosten, H. (Eds.): Landschaftsökologische Moorkunde. Second ed. E. Schweizerbart'sche Verlagsbuchhandlung, Stuttgart, 399-403.

COWIE, J. 2007: Climate change: biological and human aspects. Cambridge University Press, Cambridge.

CRAWFORD, G. 2005: East Asian plant domestication. In: Stark, M. T. (Ed.): Archaeology of Asia. Blackwell, Malden MA, 77-95.

CROWLEY, T. J., LOWERY, T. S. 2000: How Warm Was the Medieval Warm Period? Ambio 29, 51-54.

CRUMLEY, C.L. 1994: The Ecology of Conquest: Contrasting Agropastoral and Agricultural Societies' Adaptation to Climatic Change. In: Crumley, C. L. (Ed.): Historical Ecology: Cultural Knowledge and Changing Landscape. School of American Research Press, Santa Fe (New Mexico), 183-202.

D'ARRIGO, R., FRANK, D., JACOBY, G., PEDERSON, N. 2001a: Spatial response to major volcanic events in or about A.D. 536, 934 and 1258: frost rings and other dendrochronological evidence from Mongolia and northern Siberia: comment on R.B. Stothers, "Volcanic dry fogs, climate cooling, and plague pandemics in Europe and the Middle-East" (Climatic Change, 42, 1999). Climatic Change 49, 239-246.

D'ARRIGO, R., JACOBY, G., FRANK, D., PEDERSON, N., COOK, E., BUCKLEY, B., NACHIN, B., MIJIDDORJ, R., DUGARJAV, C. 2001b: 1738 Years of Mongolian temperature variability inferred from a treering width chronology of Siberian pine. Geophysical Research Letters $28,543-546$

DAVID-SIROCKO, K., SIROCKO, F. 2010: Bevölkerungswachstum und künstlerische Entfaltung zur Zeit des mittelalterlichen Wärmeoptimums. In: Sirocko, F. (Ed.): Wetter, Klima, Menschheitsentwicklung. Von der Eiszeit bis ins 21. Jahrhundert. Second ed. Wissenschaftliche Buchgesellschaft, Darmstadt, 160-164

DE BOER, J. Z., SANDERS, D. T. 2004: Volcanoes in Human History: The Far-Reaching Effects of Major Eruptions. Princeton University Press, Princeton.

DEGERBØL, M., KROG, H. 1951: Den europaeiske Sumpskildpadde (Emys orbicularis L.) i Danmark. En zoologisk or geologisk undersøgelse af danske postglaciale fund og deres betydning for bedømmelsen at temeraturforholdene i forhistorisk tid. Danmarks Geologiske Undersøgelse II, R. 78, 1-130.

DEWING, H.B. 1916: Procopius: History of the wars, Books III and IV. The Vandalic War. Harvard University Press, Cambridge MA.

DIETRICH, O., HEUN, M., NOTROFF, J., SCHMIDT, K., ZARNKOW, M. 2012: The role of cult and feasting in the emergence of Neolithic communities. New evidence from Göbekli Tepe, south-eastern Turkey Antiquity 86, 674-695.

DONAT, P., LANGE, E. 1983: Botanische Quellen und Probleme der Landwirtschaftsentwicklung im ersten Jahrtausend. Zeitschrift für Archäologie 17, 223-247.

DÖRFLER, W. 1992: Landscape development about 6500 B.P. and about 500 A.D. in Kosel, Schleswig-Holstein. In: Frenzel, B. (Ed.): Evaluation of land surfaces cleared from forests by prehistoric man in Early Neolithic times and the time of migrating Germanic tribes. Palaeoclimate Research Vol. 8 (Special Issue: ESF Project "European Palaeoclimate and Man" 3). Gustav Fischer, Stuttgart, Jena, New York, 161-167.

DOTTERWEICH, M. 2008: The history of soil erosion and fluvial deposits in small catchments of central Europe: Deciphering the longterm interaction between humans and the environment - A review Geomorphology 101, 192-208.

DRESCHER-SCHNEIDER, R. 2009: Erste pollenanalytische Untersuchungen zur Frage der bronzezeitlichen Vegetationsverhältnisse in der Hirschgrube (Dachstein, Oberösterreich). In: Hebert, B., Mandl, F. (Eds.): Almen im Visier. Dachsteingebirge, Totes Gebirge, Silvretta. Forschungsberichte der ANISA 2, 7-14.

DREßLER, M., SELIG, U., DÖRFLER, W., ADLER, S., SCHUBERT, H., HÜBENER, T. 2006: Environmental changes and the Migration Period in northern Germany as reflected in the sediments of Lake Dudinghausen.
Quaternary Research 66, 25-37.

DREXHAGE, H.-J., KONEN, H., RUFFING, K. 2002: Die Wirtschaft des Römischen Reiches (1.-3. Jahrhundert). Eine Einführung. Studienbücher Geschichte und Kultur der Alten Welt. Akademie-Verlag, Berlin.

DULL, R. 2004: Lessons from the mud, lessons from the Maya: Paleoecological records of the Tierra Blanca Joven eruption. In: Rose, W. I., Bommer, J. J., López, D. L., Carr, M. J., Major, J. J. (Eds.): Natural Hazards in El Salvador. Geological Society of America Special Paper $375,237-244$.

DUTOIT, T., THINON, M., TALON, B., BUISSON, E., ALARD, D. 2009: Sampling soil wood charcoals at a high spatial resolution: a new methodology to investigate the origin of grassland plant communities. Journal of Vegetation Science 20, 349-358.

EBERL, I. 2002: Die Zisterzienser. Geschichte eines europäischen Ordens. Thorbecke, Stuttgart.

EIRÍKSSON, J., KNUDSEN, K.L., HAFLIDASON, H., HEINMEIER, J. 2000: Chronology of late Holocene climatic events in the northern North Atlantic based on AMS $14 \mathrm{C}$ dates and tephra markers from the volcano Hekla, Iceland. Journal of Quaternary Science 15, 573-580.

EITEL, B. 2007: Kulturentwicklung am Wüstenrand - Aridisierung als Anstoß für frühgeschichtliche Innovation und Migration. In: Wagner, G. A. (Ed.): Einführung in die Archäometrie. Springer, Berlin, Heidelberg, New York, 301-319.

ELLENBERG, H. 1996: Vegetation Mitteleuropas mit den Alpen. Fifth ed. Eugen Ulmer, Stuttgart.

ELLENBERG, H., WEBER, H.E., DÜLL, R., WIRTH, V., WERNER, W., PAULISSEN, D. 1991: Zeigerwerte von Pflanzen in Mitteleuropa. Scripta Geobotanica 18.

EMANUELSSON, U. 2005: Ängar och hagar. In: Tunón, H., Pettersson, B., Iwarsson, M. (Eds.): Människan och floran. Etnobiologi i Sverige Vol. 2. Wahlström \& Widstrand, Stockholm, 139-148.

EMANUELSSON, U. 2009: The Rural Landscapes of Europe. How Man has Shaped European Nature. Formas, Stockholm.

FAGAN, B. 2000: The Little Ice Age. How Climate Made History 13501850. Basic Books, New York.

FEHN, K. 1966: Siedlungsgeschichtliche Grundlagen der Herrschaftsund Gesellschaftsentwicklung in Mittelschwaben aufgezeigt am Beispiel der spätmittelalterlichen Rodungssiedlungen. Studien zur Geschichte des bayerischen Schwabens 9. Augsburg, Verlag der Schwäbischen Forschungsgemeinschaft.

FERRIS, D. G., COLE-DAI, J., REYES, A. R., BUDNER, D. M. 2011: South Pole ice core record of explosive volcanic eruptions in the first and second millennia A.D. and evidence of a large eruption in the tropics around 535 A.D. Journal of Geophysical Research 116, D17308. DOI: 10.1029/2011JD015916.

FIRBAS, F. 1949: Waldgeschichte Mitteleuropas. Erster Band. Gustav Fischer, Jena.

FIRBAS, F. 1952: Waldgeschichte Mitteleuropas. Zweiter Band. Gustav Fischer, Jena.

FISCHER, K. 1999: Das Hungerjahr 1816/17 in Tirol und der Ausbruch des Vulkans Tambora. Der Schlern 73, 5-22.

FLECKINGER, A. 2011: Ötzi 2.0: Eine Mumie zwischen Wissenschaft, Kult und Mythos. Theiss, Stuttgart.

FORD, T.D., PEDLEY, H. M. 1996: A review of tufa and travertine deposits of the world. Earth-Science Reviews 41, 117-175.

FRENZEL, B. 1966: Climatic change in the Atlantic/sub-Boreal transition in the Northern Hemisphere: botanical evidence. In: Sawyer, J. S. (Ed.): World Climate from 8000 to 0 B.C. Proceedings of the International Symposium held at Imperial College, London, 18 and 19 April 1966. Royal Meteorological Society, London, 54-71.

FRITZ,W. 1977: Zur ökologischen Interpretation einer Moosvegetation aus dem Grabhügel Magdalenenberg. In Spindler K. (Ed.): Magdalenenberg $V$. Neckar-Verlag, Villingen, 21-34.

FRITZ, W. 1979: Hallstattzeitliche Festuca-Brometea-Rasen. In Wilmanns, O., Tüxen, R. (Eds.): Werden und Vergehen von Pflanzengesellschaften. Berichte der Internationalen Symposien der Internationen Vereinigung für Vegetationskunde (Rinteln, 20-23 March 1978), 165-180.

FRITZ, W., WILMANNS, O. 1982: Die Aussagekraft subfossiler MoosSynusien bei der Rekonstruktion eines keltischen Lebensraumes - Das Beispiel des Fürstengrabhügels Magdalenenberg bei Villingen. Berichte der Deutschen Botanischen Gesellschaft 95, 1-18. 
GAO, C., KEEN, D.H., BOREHAM, S., COOPE, G. R., PETTIT, M. E., STUART, A. J., GIBBARD, P. L. 2000: Last Interglacial and Devensian deposits of the River Great Ouse at Woolpack Farm, Fenstanton, Cambridgeshire, UK. Quaternary Science Reviews 19, 787-810.

GAUCKLER, K. 1938: Steppenheide und Steppenheidewald der Fränkischen Alb in pflanzensoziologischer, ökologischer und geographischer Sicht. Berichte der Bayerischen Botanischen Gesellschaft 23, 1-134.

GIOSAN, L., FILIP, F., CONSTATINESCU, S. 2009: Was the Black Sea catastrophically flooded in the early Holocene? Quaternary Science Reviews 28, 1-6.

GLASER, R. 2008: Klimageschichte Mitteleuropas. 1200 Jahre Wetter, Klima, Katastrophen. Second ed. Wissenschaftliche Buchgesellschaft, Darmstadt.

GOBET, E., HOCHULI, P.A., AMMANN, B., TINNER, W. 2004: Vom Urwald zur Kulturlandschaft des Oberengadins - Vegetationsgeschichte der letzten 6200 Jahre. Jahrbuch Schweizerische Gesellschaft Ur- und Frühgeschichte 87, 255-270.

GOBET, E., TINNER, W., HOCHULI, P.A., VAN LEEUWEN, J. F. N., AMMANN, B. 2003: Middle to Late Holocene vegetation history of the Upper Engadine (Swiss Alps): the role of man and fire. Vegetation History and Archaeobotany 12, 143-163.

GODWIN, H. 1975: The history of the British flora. A factual basis for phytogeography. $2^{\text {nd }}$ ed. Cambridge University Press, Cambridge.

GOOSSE, H., CRESPIN, E., DUBINKINA, S., LOUTRE, M.-F., MANN, M. E., RENSSEN, H., SALLAZ-DAMAZ, Y., SHINDELL, D. 2012a: The role of forcing and internal dynamics in explaining the "Medieval Climate Anomaly". Climate Dynamics 39(12), 2847-2866.

GOOSSE, H., GUIOT, J., MANN, M.E., DUBINKINA, S., SALLAZDAMAZ,Y. 2012b: The medieval climate anomaly in Europe: Comparison of the summer and annual mean signals in two reconstructions and in simulations with data assimilation. Global and Planetary Change 84-85, $35-47$.

GÖTTLICH, K., KUNTZE, H. 1990: Moorkultivierung für Land- und Forstwirtschaft. In: Göttlich, K. (Ed.): Moor- und Torfkunde. Third ed. E. Schweizerbart'sche Verlagsbuchhandlung, Stuttgart, 385-410.

GRADMANN, R. 1950: Pflanzenleben der Schwäbischen Alb. Erster Band. Pflanzengeographische Darstellung. Fourth ed. Schwäbischer Albverein, Stuttgart.

GRIMM, J., GRIMM, W. 1854-1960: Deutsches Wörterbuch. S. Hirzel, Leipzig.

GRINGMUTH-DALLMER，E. 2003: Die Landwirtschaft im frühen Mittelalter (6.-10. Jh.). Bodennutzungssysteme und Flurformen. In: Benecke, N., Donat, P., Gringmuth-Dallmer, E., Willerding, U. (Eds.): Frühgeschichte der Landwirtschaft in Deutschland. Beiträge zur Ur-und Frühgeschichte Mitteleuropas 14, 159-161.

GRONENBORN, D., SIROCKO, F. (2010): Frühholozänes Wärmeoptimum und neolithische Expansion. In: Sirocko, F. (Ed.): Wetter, Klima, Menschheitsentwicklung. Von der Eiszeit bis ins 21. Jahrhundert. $2^{\text {nd }}$ ed., Wissenschaftliche Buchgesellschaft, Darmstadt, 108-112.

GROSCHOPF, P., HAUFF, R., KLEY, A. 1952: Pollenanalytische Datierung Württembergischer Kalktuffe und der postglaziale KlimaAblauf. Jahreshefte der Geologischen Abteilung des Württembergischen Statistischen Landesamtes 2, 72 - 94.

GROVE, J. M. 2002: Climatic change in Northern Europe over the last two thousand years and its possible influence on human activity. In: Wefer, G., Berger, W. H., Behre, K.-E., Jansen, E. (Eds.): Climate Development and History of the North Atlantic Realm. Springer, Berlin, Heidelberg, 313-326.

GRUPE, G. 1986: Umwelt und Bevölkerungsentwicklung im Mittelalter. In: Herrmann, B. (Ed.): Mensch und Umwelt im Mittelalter. Deutsche Verlags-Anstalt, Stuttgart, 24-34.

GUIOT, J., CORONA, C., CHAVE, J. 2010: Growing Season Temperatures in Europe and Climate Forcings Over the Past 1400 Years. PLoS ONE 5(4), e9972.

GUPTA, A. K. 2004: Origin of agriculture and domestication of plants and animals linked to early Holocene climate amelioration. Current Science 87, 54-59.

HAAK, W., BALANOVSKY, O., SANCHEZ, J. J., KOSHEL, S., ZAPOROZHCHENKO, V., ADLER, C. J., DER SARKISSIAN, C. S. I., BRANDL, G., SCHWARZ, C., NICKLISCH, N., DRESELY, V., FRITSCH, B., BALANOVSKA, E., VILLEMS, R., MELLER, H., ALT,
K. W., COOPER, A., GENOGRAPHIC CONSORTIUM 2010: Ancient DNA from European Early Neolithic Farmers Reveals Their Near Eastern Affinities. PLoS Biology 8(11), e1000536.

HAARMANN, H. 2003: Geschichte der Sintflut. Auf den Spuren der frühen Zivilisation. C. H. Beck, München.

HAARMANN, H. 2011: Das Rätsel der Donauzivilisation. Die Entdeckung der ältesten Hochkultur Europas. C. H. Beck, München.

HAASE, CARL (1958): Stadtbegriff und Stadtentstehungsgeschichten in Westfalen. Überlegungen zu einer Karte der Stadtentstehungsgeschichten. Westfälische Forschungen 11, 16-32.

HÆGGSTRÖM, C.-A. 1995: Lövängar i Norden och Balticum. Nordenskiöldsamfundets Tidskrift 54, 21-58.

HÆGGSTRÖM, C.-A. 1998: Pollard meadows: multiple use of humanmade nature. In: Kirby, K. J., Watkins, C. (Eds.): The Ecological History of European Forests. CAB International, Wallingford, 33-41.

HÁJKOVÁ, P., ROLEČEK, J., HÁJEK, M., HORSÁK, M., FAJMON, K., POLÁK, M., JAMRICHOVÁ, E. 2011: Prehistoric origin of the extremely species-rich semi-dry grasslands in the Bíle Karpaty Mts (Czech Republic and Slovakia). Preslia 83, 185-204.

HALL, A. R., KENWARD, H. K. 2004: Setting people in their environment: plant and animal remains from Anglo-Scandinavian York. In: Hall, R. A., Rollason, D. W., Blackburn, M., Parsons, D. N., Fellows-Jensen, G., Hall, A. R., Kenward, H. K., O'Connor, T. P., Tweddle, D., Mainman, A. J., Rogers, N. S. H. (Eds.): Aspects of Anglo-Scandinavian York. The Archaeology of York 8(4). Council for British Archaeology and York Archaeological Trust, York, 372-426 and 507-521.

HAMILTON, F. J., BROOKS, E. W. 1899: The Syriac Chronicle Known as that of Zachariah of Mytilene. Methuen, London.

HAMM, F. 1956: Naturkundliche Chronik Nordwestdeutschlands. Landbuch-Verlag, Hannover.

HÄNDEL, D. 1967: Das Holozän der nordwestsächsischen Flussauen. Hercynia N.F. 4, 152-198.

HARINGTON, C.R. 1992: The Year Without a Summer? World Climate in 1816. Canadian Museum of Nature, Ottawa.

HARRISON, S. P., DIGERFELDT, G. 1993: European lakes as palaeohydrological and palaeoclimatic indicators. Quaternary Science Reviews 12, 233-248.

HARTHUN, M. 1998: Der Biber als Landschaftsgestalter. Schriftenreihe der Horst-Rohde Stiftung. Maecenata-Verlag, München.

HARTHUN, M. 1999: Zur Bedeutung der Biberwiesen in der mitteleuropäischen Kulturlandschaft. Natur- und Kulturlandschaft 3, 146-155.

HEATHER, P. 2005: The Fall of the Roman Empire: A New History of Rome and the Barbarians. Oxford University Press, New York.

HEMPEL, W. 2008: Die historische Entwicklung des Wirtschaftsgrünlandes in Sachsen. Berichte der Naturforschenden Gesellschaft der Oberlausitz $16,3-18$.

HEMPEL, W. 2009: Die Pflanzenwelt Sachsens von der Späteiszeit bis zur Gegenwart. Weissdorn-Verlag, Jena.

HEWITT, G.M. 1999: Post-glacial re-colonization of European biota. Biological Journal of the Linnean Society 68, 87-112.

HILLMAN, G.C. 1996: Late Pleistocene changes in wild plantfoods available to hunter-gatherers of the Northern Fertile Crescent: possible preludes to cereal cultivation. In: Harris, D. R. (Ed.): The origins and spread of agriculture and pastoralism in Eurasia. Smithsonian Institution Press, Washington, D.C, 159-203.

HILLMAN, G. C., HEDGES, R., MOORE, A., COLLEDGE, S., PETTITT, P. 2001: New evidence of Lateglacial cereal cultivation at Abu Hureyra on the Euphrates. The Holocene 11, 383-393.

HODDER, I. 2001: Symbolism and the origins of agriculture in the Near East. Cambridge Archaeological Journal 11, 107-112.

HODGKIN, T. 1886: The Letters of Cassiodorus Being a Condensed Translation of the Variae Epistolae of Magnus Aurelius Cassiodorus Senator. Henry Frowde, London.

HODGSON, J. G., HALSTEAD, P., WILSON, P. J., DAVIS, S. 1999: Functional interpretation of archaeobotanical data: making hay in the archaeological record. Vegetation History and Archaeobotany 8, 261271.

HOLLEMEYER, K. 2008: Species identification of Oetzi's clothing with matrix-assisted laser desorption/ionization time-of-flight mass spectrometry based on peptide pattern similarities of hair digests. Rapid 
Communications in Mass Spectrometry 22, 2751-2767.

HOLZHAUSER, H., MAGNY, M., ZUMBÜHL, H. J. 2005: Glacier and lake-level variations in west-central Europe over the last 3500 years. The Holocene 15, 789-801.

HORNBERGER, T. 1959: Die kulturgeographische Bedeutung der Wanderschäferei in Süddeutschland. Süddeutsche Transhumanz. Forschungen zur Deutschen Landeskunde 109, 1-173.

HUGHES, M. K., DIAZ, H. F. 1994: Was there a "Medieval Warm Period", and if so, where and when? Climatic Change 26, 109-142.

HULTÉN, E., FRIES, M. 1986: Atlas of North European Vascular Plants North of the Tropic of Cancer. Volume I to III. Koeltz Scientific Books, Königsstein.

HUNTLEY, B., BIRKS, H. J. B. 1983: An Atlas of Past and Present Pollen Maps for Europe. Cambridge University Press, Cambridge.

JACOMET, S., BROMBACHER, C. 2009: Geschichte der Flora in der Regio Basiliensis seit 7500 Jahren: Ergebnisse von Untersuchungen pflanzlicher Makroreste aus archäologischen Ausgrabungen. Mitteilungen der Naturforschenden Gesellschaften beider Basel 11, 27-106.

JANKUHN, H. 1969: Vor- und Frühgeschichte vom Neolithikum bis zur Völkerwanderungszeit. Eugen Ulmer, Stuttgart.

JESCHKE, L. 1990: Der Einfluß der Klimaschwankungen und Rodungsphasen auf die Moorentwicklung im Mittelalter. Gleditschia 18, 115-123.

JOERIN, U. E., STOCKER, T. F., SCHLÜCHTER, C. 2006: Multicentury glacier fluctuations in the Swiss Alps during the Holocene. The Holocene 16, 697-704.

JUNKELMANN, M. 2006: Panis Militaris. Die Ernährung des römischen Soldaten oder der Grundstoff der Macht. Third ed. Philipp von Zabern, Mainz.

KAPFER, A., POSCHLOD, P. 1997: Sümpfe und Moore. Weitbrecht, Stuttgart.

KARLIK, P., POSCHLOD, P. 2009: History or abiotic filter: which is more important in determining species composition of calcareous grasslands? Preslia 81, 321-340

KEYS, D. 1999: Als die Sonne erlosch. 535 n. Chr.: Eine Naturkatastrophe verändert die Welt. Karl Blessing, München.

KLEIBER, W., BINGENHEIMER, S., STEFFENS, R. 1993: Weinbau und Sprachgeschichte vom Mittel- bis zum Oberrhein. In: Gerlich, A. (Ed.) Weinbau, Weinhandel und Weinkultur. 6. Alzeyer Kolloquium 1990. Geschichtliche Landeskunde Band 40. Franz Steiner, Stuttgart, 245-281.

KNÖRZER, K.-H. 1979: Verkohlte Reste von Viehfutter aus einem Stall des römischen Reiterlagers von Dormagen. Rheinische Ausgrabungen 20, 130-137.

KNÖRZER, K.-H. 1986: Vom neolithischen Ackerbau in Rheinland Archäologie in Deutschland 1, 32-37.

KNÖRZER, K.-H. 1996: Beitrag zur Geschichte der Grünlandvegetation am Niederrhein. Tuexenia 16, 627-636.

KNÖRZER, K.-H. 2004: Geschichte der synanthropen Flora im Niederrheingebiet. Philipp von Zabern, Mainz.

KÖNIGSSON, L.K. 1968: History of the great Alvar of Öland. Acta Phytogeographica Suecica 55, 1-172.

KONNERT, M., BERGMANN, F. 1995: The geographical distribution of genetic variation of silver fir (Abies alba, Pinaceae) in relation to its migration history. Plant Systematics and Evolution 196, 19-30.

KONOLD, W. 1994: Wasserbewirtschaftung und Wassernutzung in Isny im Allgäu. In: Konold, W. (Ed.): Historische Wasserwirtschaft im Alpenraum und an der Donau. Konrad Wittwer, Stuttgart, 299-332.

KÖRBER-GROHNE, U. 1983: Die Pflanzenreste aus dem Ostkastell von Welzheim mit besonderer Berücksichtigung der Graslandpflanzen. Forschungen und Berichte zur Vor- und Frühgeschichte in BadenWürttemberg 14, 17-88.

KÖRBER-GROHNE, U. 1990: Gramineen und Grünlandvegetation vom Neolithikum bis zum Mittelalter in Mitteleuropa. Bibliotheca Botanica 139, 1-104.

KÖRBER-GROHNE, U. 1994: Nutzpflanzen in Deutschland. Kulturgeschichte und Biologie. Third ed. Konrad Theiss, Stuttgart.

KREUZ, A. 2008: Closed forests or open woodland as natural vegetation in the surroundings of Linearbandkeramik settlements? Vegetation History and Archaeobotany 17, 51-64.

KREUZ, A., SCHÄFER, E. 2011: Weed finds as indicators for the cultivation regime of the early Neolithic Bandkeramik culture? Vegetation History and Archaeobotany 20, 333-348.

KROLL, M. 1973: Der Fasan - seine Lebensweise, Hege und Jagd. Third ed. Neumann, Radebeul.

KRONFELD, E. M. 1919: Sagenpflanzen und Pflanzensagen. Theodor Thomas-Verlag, Leipzig.

KUKK, T., KULL, K. 1997: Puisniidud. Estonia Maritima 2, 1-249.

KUNEŠ, P., SVOBODOVÁ-SVITASKÁ, H., KOLÁR, J., HAJNALOVÁ, M., ABRAHAM, V., MACEK, M., TKÁC, P., SZABÓ, P. (2015): The origin of grasslands in the temperate forest zone of east-central Europe: long-term legacy of climate and human impact. Quaternary Science Reviews 116, 15-27.

KÜSTER, H. 1988: Vom Werden einer Kulturlandschaft. Vegetationsgeschichtliche Studien am Auerberg (Südbayern). VCH, Acta Humaniora, Weinheim.

KÜSTER, H. 1994: Botanische Untersuchungen zur Landwirtschaft in den Rhein-Donau-Provinzen vom 1. bis zum 5. Jahrhundert nach Chr. In: Bender, H., Wolff, H. (Eds.): Ländliche Besiedlung und Landwirtschaft in den Rhein-Donau-Provinzen des römischen Reiches. Passauer Universitäts-Schriften zur Archäologie 2(I), 21-36, 2(II), 7-13.

KÜSTER, H. 1997: The role of farming in the postglacial expansion of beech and hornbeam in the oak woodlands of central Europe. The Holocene 7, 239-242.

LAMB, H. H. 1965: The early medieval warm epoch and its sequel. Palaeogeography, Palaeoclimatology, Palaeoecology 1, 13-37.

LAMB, H. H. 1977: Climate. Present, Past and Future. Volume 2: Climatic History and the Future. Methuen \& Co Ltd and Barnes \& Nobles Books, London, New York.

LAMB, H. H. 1995: Climate, History and the Modern World. Second ed. Routledge, London.

LANG, G. 1994: Quartäre Vegetationsgeschichte Europas. Gustav Fischer, Jena, Stuttgart, New York.

LANGE, E., ILLIG, H., ILLIG, J., WETZEL, G. 1978: Beiträge zur Vegetations- und Siedlungsgeschichte der nordwestlichen Niederlausitz. Abhandlungen Berichte Naturkundemuseum Görlitz 52/3, 1-80.

LARSEN, L. B., VINTHER, B. M., BRIFFA, K. R., MELVIN, T. M., CLAUSEN, H. B., JONES, P. D., SIGGAARD-ANDERSEN, M.-L., HAMMER, C. U., ERONEN, M., GRUDD, H., GUNNARSON, B. E., HANTEMIROV, R. M., NAURZBAEV, M. M., NICOLUSSI, K. 2008: New ice core evidence for a volcanic cause of the A.D. 536 dust veil. Geophysical Research Letters 35(4), L04708.

LE ROY LADURIE, E. 1967: Histoire du climat depuis l'an mil. Flammarion, Paris.

LE ROY LADURIE, E. 2004: Histoire humaine et comparée du climat. I. Canicules et glaciers (XIIIe-XVIIIe siècle). Fayard, Paris.

LE ROY LADURIE, E. 2006: Histoire humaine et comparée du climat. II. Disettes et révolutions (1740-1860). Fayard, Paris.

LE ROY LADURIE, E. 2009a: Histoire humaine et comparée du climat. III. Le réchauffement de 1860 à nos jours. Fayard, Paris.

LE ROY LADURIE, E. 2009b: Histoire du climat depuis l'an mil. Tome 1. Third ed. Flammarion, Paris.

LE ROY LADURIE, E. 2009c: Histoire du climat depuis l'an mil. Tome 2. Third ed. Flammarion, Paris.

LEAN, J. 2002: Solar Forcing of climate Change in Recent Millenia. In: Wefer, G., Berger, W. H., Behre, K.-E., Jansen, E. (Eds.): Climate Development and History of the North Atlantic Realm. Springer, Berlin, Heidelberg, 75-88.

LERICOLAIS, G., BULOIS, C., GILLET, H., GUICHARD, F. 2009: High frequency sea level fluctuations recorded in the Black Sea since the LGM. Global and Planetary Change 66, 65-75.

LEUBE, A. 2003: Die Landwirtschaft im freien Germanien. Geräte zur Bodenbearbeitung, zur Ernte und Verarbeitung von Feldfrüchten. In: Benecke, N., Donat, P., Gringmuth-Dallmer, E., Willerding, U. (Eds.): Frühgeschichte der Landwirtschaft in Deutschland. Beiträge zur Ur- und Frühgeschichte Mitteleuropas 14, 97-112.

LJUNGQVIST, F.C. 2010: A new reconstruction of temperature variability in the extra-tropical Northern Hemisphere during the last two millennia. Geografiska Annaler 92 A, 339-351.

LOEHLE, C. 2007: A 2000-year global temperature reconstruction based on non-treering proxies. Energy \& Environment 18, 1049-1058.

LOHMEYER, W., SUKOPP, H. 1992: Agriophyten in der Vegetation Mitteleuropas. Schriftenreihe für Vegetationskunde 25, 1-185. 
LOŽEK, V. 1961: Stratigrafický výzkum travertinu u Skřečoně. Anthropozoikum 9, 35-45.

LOŽEK, V. 1963: K otázce tvorby svahových sutí v Českém krasu. Československý kras 14, 7-16.

LOŽEK, V. 1964: Quartärmollusken der Tschechoslowakei. Rozpravy Ústředního Ústavu Geologického 31, 1-374.

LÜNING, J. 2000: Steinzeitliche Bauern in Deutschland. Die Landwirtschaft im Neolithikum. Universitätsforschungen zur Prähistorischen Archäologie Band 58. Dr. Rudolf Habelt, Bonn.

LUTERBACHER, J., DIETRICH, D., XOPLAKI, E., GROSJEAN, M., WANNER, H. 2004: European seasonal and annual temperature variability, trends and extremes since 1500. Science 303, 1499-1503.

MAGNY, M., HAAS, J. N. 2004: A major widespread climatic change around $5300 \mathrm{cal}$. yr BP at the time of the Alpine Iceman. Journal of Quaternary Science 19, 423-430.

MAGNY, M., LEUZINGER, U., BORTENSCHLAGER, S., HAAS, J. N. 2006: Tripartite climate reversal in Central Europe 5600-5300 years ago. Quaternary Research 65, 3-19.

MAGRI, D. 2008: Patterns of post-glacial spread and the extent of glacial refugia of European beech (Fagus sylvatica). Journal of Biogeography $35,450-463$.

MAGRI, D., VENDRAMIN, G. G., COMPS, B., DUPANLOUP, I., GEBUREK, T., GÖMÖRY, D., LATAEOWA, M., LITT, T., PAULE, L., ROURE, J. M., TANTAU, I., VAN DER KNAAP, W. O., PETIT, R. J., DE BEAULIEU, J.-L. 2006: A new scenario for the Quaternary history of European beech populations: palaeobotanical evidence and genetic consequences. New Phytologist 171, 199-221.

MALMSTRÖM, H., GILBERT, M. T. P., THOMAS, M. G., BRANDSTRÖM, M., STORA, J., MOLNAR, P., ANDERSEN, P. K., BENDIXEN, C., HOLMLUND, G., GÖTHERSTRÖM, A., WILLERSLEV, E. 2009: Ancient DNA reveals lack of continuity between Neolithic hunter-gatherers and contemporary Scandinavians. Current Biology 19, 1758-1762.

MANDL, F. 2007a: Die Königreichalm. Heimhöfe und Alm in historischer Sicht. In: Hebert, B., Kienast, G., Mandl, F. (Eds.): Königreichalm. Dachsteingebirge. 3500 Jahre Almwirtschaft zwischen Gröbming und Hallstatt. Forschungsberichte der ANISA 1, 7-22.

MANDL， F. 2007b: Das „Königreich“ auf dem Dachsteingebirge. Dokumentationen. In: Hebert, B., Kienast, G., Mandl, F. (Eds.): Königreichalm. Dachsteingebirge. 3500 Jahre Almwirtschaft zwischen Gröbming und Hallstatt. Forschungsberichte der ANISA 1, 23-96.

MANDL, F. 2009: Hallstatts bronzezeitliche Almen. In: Schmidt, R., Matulla, C., Psenner, R. (Eds.): Klimawandel in Österreich. Die letzten 20.000 Jahre ... und ein Blick voraus. alpine space - man \& environment 6. Innsbruck University Press, Innsbruck, S. 97-104.

MANGERUD, J., ANDERSEN, S.T., BERGLUND, B. E., DONNER, J. J. 1974: Quaternary stratigraphy of Norden, a proposal for terminology and classification. Boreas 3, 109-128.

MANN, M. E., BRADLEY, R. S., HUGHES, M. K. 1999: Northern Hemisphere temperatures during the past millennium: Inferences, uncertainties, and limitations. Geophysical Research Letters 26, 759-762.

MANN, M. E., ZHANG, Z., HUGHES, M. K., BRADLEY, R. S., MILLER, S., RUTHERFORD, S., NI, F. 2008: Proxy-based reconstructions of hemispheric and global surface temperature variations over the past two millennia. Proceedings of the National Academy of Sciences of the USA $105,13252-13257$.

MANN, M. E., ZHANG, Z., RUTHERFORD, S., BRADLEY, R. S., HUGHES, M. K., SHINDELL, D., AMMANN, C., FALUVEGI, G., NI, F. B. 2009: Global signatures and dynamical origins of the Little Ice Age and Medieval Climate Anomaly. Science 324, 1256-1260.

MANSFIELD, H. 2011: Roman Snail: An introduction to its ecology and legal protection. Practice (Bulletin of the Institute of Ecology and Environmental Management) 72, 26-29.

MCCORRSITON, J., HOLE, F. 1991: The ecology of seasonal stress and the origins of agriculture in the Near East. American Anthropology 93 , 46-69.

MENSCHING, H. 1951: Akkumulation und Erosion niedersächsischer Flüsse seit der Risseiszeit. Erdkunde 5, 60-70.

MEUSEL, H. 1935: Die Waldtypen des Grabfeldes und ihre Stellung innerhalb der Wälder zwischen Main und Werra. Beiheft Botanisches Centralblatt 53, 175-251.
MEUSEL, H. 1939: Die Vegetationsverhältnisse der Gipsberge am Kyffhäuser und im südlichen Harzvorland. Ein Beitrag zur Steppenheidefrage. Hercynia 2, 1-372.

MILISAUSKAS, S. 2011: Early Neolithic, the First Farmers in Europe, 7000-5500/5000 BC. In: Milisauskas, S. (Ed.): European Prehistory. A Survey. Interdisciplinary Contributions to Archaeology. Second ed. Springer, New York, Dordrecht, Heidelberg, London, 153-221.

MILLER, G. F., GEIRSDOTTIR, A., ZHONG, Y., LARSEN, D. J., OTTO-BLIESNER, B. L., HOLLAND, M. M., BAILEY, D. A., REFSNIDER, K. A., LEHMAN, S. J., SOUTHON, J. R., ANDERSON, C., BJÖRNSSON, H., THORDARSON, T. 2012: Abrupt onset of the Little Ice Age triggered by volcanism and sustained by sea-ice/ocean feedbacks. Geophysical Research Letters 39(2), L02708.

MITCHELL, F. 2005: How open were European primeval forests? Hypothesis testing using palaeoecological data. Journal of Ecology 93, 168-177.

MOBERG, A., SONECHKIN, D. M., HOLMGREN, K., DATSENKO, N., KARLÉN, W. 2005: Highly Variable Northern Hemisphere Temperatures reconstructed from low- and high-resolution proxy data. Nature 433, 613-617.

MÜLLER, J. 2011: Megaliths and funnel Beakers: Societies in Change 4100-2700 BC. 33. Kroon-Voordracht, Amsterdams Archeologisch Centrum, Amsterdam.

MÜLLER, T. 1980: Der Scheidenkronwicken-Föhrenwald (CoronilloPinetum) und der Geißklee-Föhrenwald (Cytiso-Pinetum) auf der Schwäbischen Alb. Phytocoenologia 7, 392-412.

MÜLLER, W., FRICKE, H., HALLIDAY, A. N., MCCULLOCH, M. T., WARTHO, J.-A. 2003: Origin and migration of the alpine iceman. Science 302, 862-866.

MÜLLER-WILLE, M., DÖRFLER, W., MEIER, D., KROLL, H. 1988: The transformation of rural society economy and landscape during the first Millennium AD: archaeological and palaeobotanical contributions from Northern Germany and Southern Scandinavia. Geografiska Annaler 70B, 53-68.

MUSCHELER, R., JOOS, F., BEER, J., MULLER, S. A., VONMOOS, M., SNOWBALL, I. 2007: Solar activity during the last $1000 \mathrm{yr}$ inferred from radionuclide records. Quaternary Science Reviews 26, 82-97.

NASU, H., MOMOHARA, A., YASUDA, Y., HE, J. 2007: The occurrence and identification of Setaria italica (L.) P. Beauv. (foxtail millet) grains from the Chengtoushan site (ca. 5800 cal B.P.) in central China, with reference to the domestication centre in Asia. Vegetation History and Archaeobotany 16, 481-494.

NELLE, O. 2002: Zur holozänen Vegetations- und Waldnutzungsgeschichte des Vorderen Bayerischen Waldes anhand von Pollen- und Holzkohleanalysen. Hoppea, Denkschriften der Regensburgischen Botanischen Gesellschaft 63, 161-361.

NICOLUSSI, K., KAUFMANN, M., PATZELT, G., VAN DER PLICHT, J., THURNER, A. 2005: Holocene tree-line variability in the Kauner Valley, Central Eastern Alps, indicated by dendrochronological analysis of living trees and subfossil logs. Vegetation History and Archaeobotany 14, 221-234.

NIETHAMMER, G. 1963: Die Einbürgerung von Säugetieren und Vögeln in Europa. Paul Parey, Hamburg.

NUSSBAUMER, S. U., STEINHILBER, F., TRACHSEL, M., BREITENMOSER, P., BEER, J., BLASS, A., GROSJEAN, M., HAFNER, A., HOLZHAUSER, H., WANNER, H., ZUMBÜHL, H. J. 2011: Alpine climate during the Holocene: a comparison between records of glaciers, lake sediments and solar activity. Journal of Quaternary Science 26, 703-713.

OSBORNE, P.J. 1972: Insect faunas of Late Devensian and Flandrian age from Chuch Stretton, Shropshire. Philosophical Transactions of the Royal Society of London Series B 263, 327-367.

OSBORNE, P.J. 1997: Insects, man and climate in the British Holocene. In: Ashworth, A. C., Buckland, P. C., Sadler, J. P. (Eds.): Studies in Quaternary Entomology - an Inordinate Fondness for Insects. Quaternary Proceedings No. 5. John Wiley \& Sons, Chichester, 193-198. OVERBECK, F. 1975: Botanisch-geologische Moorkunde unter besonderer Berücksichtigung der Moore Nordwestdeutschlands als Quellen zur Vegetations-, Klima- und Siedlungsgeschichte. Wachholtz, Neumünster.

ÖZDOĞAN, M. 2002: Defining the Neolithic of Central Anatolia. In: Gérard, F., Thissen, L. (Eds.): The Neolithic of Central Anatolia. Internal 
Developments and External Relations during the $9^{\text {th }}-6^{\text {th }}$ Millenia cal BC. Proceedings of the International CANew Table Ronde Istanbul, 23-24 November 2001. EGE Yayinlari, Institut Français d'Études Anatoliennes - Georges Dumézil, British Institute of Archaeology and Malcolm and Carolyn Wiener Laboratory for Aegean and Near Eastern Dendrochronology at Cornell University, Istanbul, Ankara, Ithaca, 253261.

ÖZDOĞAN, M. 2011: Archaeological Evidence on the Westward Expansion of Farming Communities from Eastern Anatolia to the Aegean and the Balkans. Current Anthropology 52 (Supplement 4), 415-430.

PAGES 2K CONSORTIUM 2013: Continental-scale temperature variability during the past two millennia. Nature Geoscience 6(5), 339-346.

PAUL, H., RUOFF, S. 1932: Pollenstatistische und stratigraphische Mooruntersuchungen im südlichen Bayern. II. Teil: Moore in den Gebieten der Isar-, Allgäu- und Rheinvorlandgletscher. Berichte der Bayerischen Botanischen Gesellschaft 20, 1-264.

PENTECOST, A. 1995: Quaternary travertine deposits of Europe and Asia Minor. Quaternary Science Reviews 14, 1005-1028.

PETERS, J. 1994: Nutztiere in den westlichen Rhein-Donau-Provinzen während der Römischen Kaiserzeit. In: Bender, H., Wolff, H. (Eds.): Ländliche Besiedlung und Landwirtschaft in den Rhein-Donau-Provinzen des römischen Reiches. Passauer Universitäts-Schriften zur Archäologie 2(I), 37-63.

PETERSEN, M., ROHDE, H. 1977: Sturmflut. Die großen Fluten an den Küsten Schleswig-Holsteins und in der Elbe. Wachholtz, Neumünster.

POKORNÝ, P. 2005: Role of man in the development of Holocene vegetation in Central Bohemia. Preslia 77, 113-128.

POKORNÝ, P., KLIMEŠOVÁ, J., KLIMEŠ, L. 2000: Late Holocene history and vegetation dynamics of a floodplain alder carr: a case study from eastern Bohemia, the Czech Republic. Folia Geobotanica Phytotaxonomica 35, 43-58.

POKORNÝ, P., CHYTRÝ, M., JUŘIČKOVÁ, L., SÁDLO, J., NOVÁK, J. LOŽEK, V. 2015: Mid-Holocene bottleneck for central European dry grasslands: Did steppe survive the forest optimum in northern Bohemia, Czech Republic? The Holocene 25, 716-726.

POSCHLOD, P. 2014: Kulturlandschaft, Landnutzungswandel und Vielfalt - Mechanismen und Prozesse der Entstehung und Entwicklung unserer Kulturlandschaft und die Notwendigkeit einer Genbank für ,Wildpflanzen für Ernährung und Landwirtschaft (WEL)“. In: Poschlod, P., Borgmann, P., Listl, D., Reisch, C., Zachgo, S., Genbank WEL-Netzwerk (Eds.): Handbuch Genbank WEL. Hoppea, Denkschriften der Regensburgischen Botanischen Gesellschaft, Sonderband, 7-40.

POSCHLOD, P. 2015: Geschichte der Kulturlandschaft. Eugen Ulmer, Stuttgart.

POSCHLOD, P., BAUMANN, A. 2010: The historical dynamics of calcareous grasslands in the Central and Southern Franconian jurassic mountains - a comparative pedoanthracological and pollen analytical study. The Holocene 20, 13-23.

POSCHLOD, P., BONN, S. 1998: Changing dispersal processes in the central European landscape since the last ice age - an explanation for the actual decrease of plant species richness in different habitats. Acta Botanica Neerlandica 47, 27-44.

POSCHLOD P., KARLÍK P., BAUMANN A., WIEDMANN B. 2008: The history of dry calcareous grasslands near Kallmünz (Bavaria) reconstructed by the application of palaeoecological, historical and recent-ecological methods. In: Szabó P., Hédl R. (Eds.), Human Nature: Studies in Historical Ecology and Environmental History. Institute of Botany of the Czech Academy of Sciences, Průhonice, 130-143.

POSCHLOD, P., BAUMANN, A., KARLIK, P. 2009a: Entstehung und Entwicklung von Grünland (Kulturgrasland) in Mitteleuropa. In Schreiber, K.-F., Brauckmann, H.-J., Broll, G., Krebs, S., Poschlod, P. (Eds.): Landschaftspflege und Naturschutz im Extensivgrünland. 30 Jahre Offenhaltungsversuche Baden-Württemberg. NaturschutzSpectrum Themen 97, 37-48.

POSCHLOD, P., BAUMANN, A., KARLIK, P. 2009b: Origin and development of grasslands in central Europe. In: Veen, P., Jefferson, R., De Smidt, J., Van der Straaten, J. (Eds.): Grasslands in Europe - of high nature value. KNNV Publishing, Zeist, 15-25.

POSCHLOD, P., WALLISDEVRIES, M. F. 2002: The historical and socioeconomic perspective of calcareous grasslands - lessons from the distant and recent past. Biological Conservation 104, 361-376.
POTT, R. 1999: Lüneburger Heide. Wendland und Nationalpark Mittleres Elbtal. Eugen Ulmer, Stuttgart.

PREECE, R. C., BRIDGLAND, D. R. 1999: Holywell Coombe, Folkestone: a 13,000 year history of an English chalkland valley. Quaternary Science Reviews 18, 1075-1125.

RABENSTEIN, P. 1982: Jan von Moor. Ein Heimatbuch vom Teufelsmoor. Atelier im Bauernhaus, Fischerhude.

RACKHAM, H. 1945: Pliny. Natural History, Volume IV, Books 12-16. Loeb Classical Library 370. Harvard University Press, Cambridge MA.

RADKE, G. J. 1973: Landschaftsgeschichte und -ökologie des Nordschwarzwaldes. Hohenheimer Arbeiten 68. Eugen Ulmer, Stuttgart.

RAMPINO, M. R., SELF, S., STOTHERS, R. B. 1988: Volcanic Winter. Annual Review of Planet Earth Science 16, 73-99.

REICHHOLF, J. 2008: Warum die Menschen sesshaft wurden. Das größte Rätsel unserer Geschichte. S. Fischer, Frankfurt a. M.

REITMAIER, T., WALSER BAKK, U. 2008: Ein grenzüberschreitendes archäologisches Projekt in Silvretta. URL: http:// www.anisa.at/silvretta reitmaier 2008 pdf.pdf.

REITMAIER, T. 2009: Rückwege - Archäologie im Silvrettagebirge. In: Hebert, B., Mandl, F. (Eds.): Almen im Visier. Dachsteingebirge, Totes Gebirge, Silvretta. Forschungsberichte der ANISA 2, 167-176.

RICHERSON, P. J., BOYD, R., BETTINGER, R. L. 2001: Was agriculture impossible during the Pleistocene but mandatory during the Holocene? A climate change hypothesis. American Antiquity 66, 387-412.

RICHTER, W. 1981: Lucius Iunius Moderatus Columella. Zwölf Bücher über Landwirtschaft. Buch eines Unbekannten über Baumzüchtung. Lateinisch - Deutsch. Band I. Artemis, München.

RIECKHOFF, S., FICHTL, S. 2011: Die Keltenstädte aus der Luft. Konrad Theiss, Stuttgart.

RIGBY, E., SYMONDS, M., WARD-THOMPSON, D. 2004: A comet impact in AD 536? Astronomy \& Geophysics 45, 23-26.

ROBERTS, N. 1998: The Holocene. Second ed. Blackwell-Wiley, Oxford.

ROBIN, V., NADEAU, M.-J., GROOTES, P. M., BORK, H.-R., NELLE, O. (2016): Too early and too northerly: evidence of temperate trees in northern central Europe during the Younger Dryas. New Phytologist, Doi: $10.1111 /$ nph.13844.

RÖSCH, M. 1990: Vegetationsgeschichtliche Untersuchungen im Durchenbergried. Siedlungsarchäologie im Alpenvorland 2. Forschungen und Berichte zur Vor- und Frühgeschichte in Baden-Württemberg 37, 9-56.

RÖSCH, M. 1991: Veränderungen von Wirtschaft und Umwelt während Neolithikum und Bronzezeit am Bodensee. Berichte der RömischGermanischen Kommission 71, 161-186.

RÖSCH, M., HEUMÜLLER, M. 2008: Vom Korn der frühen Jahre Sieben Jahrtausende Ackerbau und Kulturlandschaft. Archäologische Informationen aus Baden-Württemberg 55, 1-102.

RYAN, W. B. F., PITMAN III, W. C. 1998: Noah's Flood: the New Scientific Discoveries about Events that Changed History. Simon \& Schuster, New York

RYAN, W. B. F., MAJOR, C. O., LERICOLAIS, G., GOLDSTEIN, S. L. 2003: Catastrophic flooding of the Black Sea. Annual Review of Earth and Planetary Sciences 31, 525-554.

RYAN, W. B. F., PITMAN III, W. C., MAJOR, C. O., SHIMKUS, K., MOSKALENKO, V., JONES, G. A., DIMITROV, P., GORÜR, N., SAKINÇ, M., YÜCE, H. 1997: An abrupt drowning of the Black Sea Shelf. Marine Geology 138, 119-126.

SÁDLO, J. 2000: Původ travinné vegetace slatin v Čechách: sukcese kontra cenogeneze. Preslia 72, 495-506.

SCHEITLIN, P. 1820: Meine Armenreisen in den Kanton Glarus und in die Umgebung der Stadt St. Gallen in den Jahren 1816 und 1817 , nebst einer Darstellung, wie es den Armen des gesammten Vaterlandes im Jahr 1817 erging. Ein Beytrag zur Charakteristik unsrer Zeit. In Abendunterhaltungen für die Jugend, jedoch für Jedermann. Huber und Compagnie, St. Gallen.

SCHENK, W. 2000: Hochacker. In: Hoops, J., Beck, H., Geuenich, D., Steuer, H. (Eds.): Reallexikon der germanischen Altertumskunde. Band 15: Hobel - Iznik. Second ed., De Gruyter, Berlin, 5-8.

SCHIER, W. 2009: Extensiver Brandfeldbau und die Ausbreitung der neolithischen Wirtschaftsweise in Mitteleuropa und Südskandinavien am Ende des 5. Jahrtausends v. Chr. Praehistorische Zeitschrift 84, 15-43.

SCHNEIDER, J. 1996: Auswirkungen des Bibers auf die Auenlandschaft. 
Natur- und Kulturlandschaft 1, 175-179.

SCHÖNWIESE, C. 1995: Klimaänderungen. Daten, Analysen, Prognosen. Springer, Berlin, Heidelberg.

SCHREG, R. 2010: Siedlungsverdichtung und Stollenbau - der Mensch gestaltet die Landschaft nach seinen Vorstellungen. In: Sirocko, F. (Ed.): Wetter, Klima, Menschheitsentwicklung. Von der Eiszeit bis ins 21. Jahrhundert. Second ed. Wissenschaftliche Buchgesellschaft, Darmstadt, 154-159.

SCHREG, R., SIROCKO, F. 2010: Völkerwanderung und Umweltkrise das Ende des römischen Weltreiches. In: Sirocko, F. (Ed.): Wetter, Klima, Menschheitsentwicklung. Von der Eiszeit bis ins 21. Jahrhundert. Second ed. Wissenschaftliche Buchgesellschaft, Darmstadt, 150-153.

SCHRÖDER-LEMBKE, G. 1978: Studien zur Agrargeschichte. Quellen und Forschungen zur Agrargeschichte Band 31. Gustav Fischer, Stuttgart, New York.

SCHWERZ, J. N. 1816a: Beobachtungen über den Ackerbau der Pfälzer. Carl Gesold, Wien.

SCHWERZ, J. N. 1816b: Beschreibung der Landwirthschaft im NiederElsaß. G. Reimer, Berlin.

SCHWICKERATH, M. 1954: Die Landschaft und ihre Wandlung auf geobotanischer und geographischer Grundlage entwickelt und erläutert im Bereich des Meßtischblattes Stolberg. Dr. Rudolf Georgi, Aachen.

SHINDELL, D.T., SCHMIDT, G.A., MANN, M.E., RIND, D., WAPLE, A. 2001: Solar forcing of regional climate change during the Maunder Minimum. Science 294, 2149-2152.

SHINDELL, D. T., SCHMIDT, G. A., MILLER, R., MANN, M. E. 2003: Volcanic and solar forcing of climate change during the pre-industrial era. Journal of Climate 16, 4094-4107.

SIROCKO, F. 2010: Wetter, Klima, Menschheitsentwicklung. Von der Eiszeit bis ins 21. Jahrhundert. Second ed. Wissenschaftliche Buchgesellschaft, Darmstadt.

SMETÁNKA, Z. 2009: Die Geschichte vom Bauern Ostoj. Alltag im mittelalterlichen Böhmen. Verlag Marie Leidorf, Rahden/Westfalen.

SMITH, C. T. 1978: An Historical Geography of Western Europe before 1800 (Geographies for Advanced Study). Revised ed. Longman, New York

SOLANKI, S. K., USOSKIN, I. G., KROMER, B., SCHÜSSLER, M., BEER, J. 2004: Unusual activity of the Sun during recent decades compared to the previous 11,000 years. Nature 431, 1084-1087.

SOMMER, R. S., LINDQVIST, C., PERSSON, A., BRINGSØE, H., RHODIN, A. G. J., SCHNEEWEISS, N., ŠIROKÝ, P., BACHMANN, L., FRITZ, U. 2009: Unexpected early extinction of the European pond turtle (Emys orbicularis) in Sweden and climatic impact on its Holocene range. Molecular Ecology 18, 1252-1262.

SOMMER, R. S., PERSSON, A., WIESEKE, N., FRITZ, U. 2007: Holocene recolonization and extinction of the pond turtle, Emys orbicularis (L., 1758), in Europe. Quaternary Science Reviews 26, 3099-3107.

SPECKER, L. 1993: Die grosse Heimsuchung. Das Hungerjahr 1816/17 in der Ostschweiz. Erster Teil. Historischer Verein des Kantons St. Gallen. Neujahrsblatt 133, 5-42.

SPECKER, L. 1995: Die grosse Heimsuchung. Das Hungerjahr 1816/17 in der Ostschweiz. Zweiter Teil. Historischer Verein des Kantons St. Gallen. Neujahrsblatt 135: 5-56.

SPEIER, M. 1994: Vegetationskundliche und paläoökologische Untersuchungen zur Rekonstruktion prähistorischer und historischer Landnutzungen im südlichen Rothaargebirge. Abhandlungen aus dem Westfälischen Museum für Naturkunde 56(3/4), 1-174.

STARKEL, L. 1966: Post-glacial climate and the moulding of European relief. In: Sawyer, J.S. (Ed.): World Climate from 8000 to 0 B.C. Proceedings of the International Symposium held at Imperial College, London, 18 and 19 April 1966. Royal Meteorological Society, London, 15-33.

STEINHILBER, F., ABREU, J.A., BEER, J. 2008: Solar modulation during the Holocene. Astrophysics and Space Sciences Transactions 4, 1-6.

STEINHILBER, F., BEER, J., FRÖHLICH, C. 2009: Total solar irradiance during the Holocene. Geophysical Research Letters 36(19), L19704.

STOLZ, C., GRUNERT, J. 2008: Floodplain sediments of some streams in the Taunus and Westerwald Mts., western Germany, as evidence of historical land use. Zeitschrift für Geomorphologie N.F. 52, 349-373.

STOMMEL, H., STOMMEL, E. 1983: Volcano Weather. The Story of the Year without Summer 1816. Seven Seas Press, Newport, Rhode Island.
STOOB, H. 1956: Kartographische Möglichkeiten zur Darstellung der Stadtentstehung in Mitteleuropa, besonders zwischen 1450 und 1800. In: Stoob, H. (Ed.): Forschungen zum Städtewesen in Europa. Band I. Räume, Formen und Schichten der mitteleuropäischen Städte. Böhlau, Köln, Wien, 15-42.

STOTHERS, R. B. 1984a: Mystery cloud of AD 536. Nature 307, 344-345. STOTHERS, R. B. 1984b: The great Tambora eruption in 1815 and its aftermath. Science 224, 1191-1198.

STOTHERS, R. B., RAMPINO, M. R. 1983: Volcanic Eruptions in the Mediterranean Before A.D. 630 From Written and Archaeological Sources. Journal of Geophysical Research 88, 6357-6371.

STUART, A. J., KOSINTSEV, P. A., HIGHAM, T. F. G., LISTER, A. M. 2004: Pleistocene to Holocene extinction dynamics in giant deer and woolly mammoth. Nature 431, 684-689.

SUCCOW, M., JESCHKE, L. 1986: Moore in der Landschaft. Entstehung, Haushalt, Lebewelt, Verbreitung, Nutzung und Erhaltung der Moore. Urania, Leipzig, Jena, Berlin.

TALON, B., CARCAILlET, C., THINON, M. 1998: Études pédoanthracologiques des variations de la limité supérieure des arbres au cours de l'holocene dans les alpes francaises. Géographie Physique et Quaternaire 52, 195-208.

TANNO, K., WILLCOX, G. 2006: The origins of cultivation of Cicer arietinum L. and Vicia faba L.: early finds from Tell el-Kerkh, north-west Syria, late $10^{\text {th }}$ millennium B.P. Vegetation History and Archaeobotany 15, 197-204.

TETZLAFF, G., BÖRNGEN, M., MUDELSEE, M., RAABE, A. 2002: Das Jahrtausendhochwasser von 1342 am Main aus meteorologischhydrologischer Sicht. Wasser und Boden 54/10, 41-49.

THIEL, A. 2008: Die Römer in Deutschland. Konrad Theiss, Stuttgart.

THOM, N. 2010: A hydrological model of the Black and Caspian Seas in the late Pleistocene and early-middle Holocene. Quaternary Science Reviews 29, 2989-2995.

TINNER, W., HUBSCHMID, P., WEHRLI, M., AMMANN B., CONEDERA, M. 1999: Long-term forest fire ecology and dynamics in southern Switzerland. Journal of Ecology 87, 273-289.

TINNER, W., LOTTER, A. F. 2006: Holocene expansions of Fagus silvatica and Abies alba in Central Europe: where are we after eight decades of debate? Quaternary Science Reviews 25, 526-549.

TROUET, V., ESPER, J., GRAHAM, N., BAKER, A., SCOURSE, J. D., FRANK, D. C. 2009: Persistent positive North Atlantic Oscillation mode dominated the Medieval Climate Anomaly. Science 324, 78-80.

VAN LOON, H., BROWN, J., MILLIFF, R. F. 2012: Trends in sunspots and North Atlantic sea level pressure. Journal of Geophysical Research: Atmospheres 117(D7), D07106.

VERA, F. 2000: Grazing Ecology and Forest History. CABI Publishing, Wallingford.

VON POST, L. 1946: The prospect for pollen analysis in the study of earth's climatic history. New Phytologist 45, 193-217.

VONMOOS, M., BEER, J., MUSCHELER, R. 2006: Large variations in Holocene solar activity: Constraints from $10 \mathrm{Be}$ in the Greenland Ice Core Project ice core. Journal of Geophysical Research 111(A10), A10105.

WALKER, M. J. C., BERKELHAMMER, M., BJÖRCK, S., CWYNAR, L. C., FISHER, D. A. LONG, A. J., LOWE, J. J., NEWNHAM, R. M., RASMUSSEN, S. O., WEISS, H. 2012: Formal subdivision of the Holocene Series/Epoch: a Discussion Paper by a Working Group of INTIMATE (Integration of ice-core, marine and terrestrial records) and the Subcommission on Quaternary Stratigraphy (International Commission on Stratigraphy). Journal of Quaternary Science 27, 649659.

WALL, E. 1961: Der Federsee von der Eiszeit bis zur Gegenwart. In: Zimmermann, W. (Ed.): Der Federsee. Verlag des Schwäbischen Albvereins, Stuttgart, 228-315.

WATKINS, T. 2007: Der Naturraum in Anatolien. Ein Zusammenspiel von Klima, Umwelt und Ressourcen. In: Badisches Landesmuseum Karlsruhe (Ed.): Vor 12.000 Jahren in Anatolien. Die ältesten Monumente der Menschheit. Badisches Landesmuseum Karlsruhe, Konrad Theiss, Stuttgart, 37-47.

WEBER, W. 1980: Die Entwicklung der nördlichen Weinbaugrenze in Europa. Forschungen zur Deutschen Landeskunde 216, 1-310.

WEGENER, A. 1985: Die Besiedlung der nordwestdeutschen Hochmoore. Telma $15,151-172$. 
WEIKINN, C. 1958: Quellentexte zur Witterungsgeschichte Europas von der Zeitenwende bis zum Jahre 1850, Hydrographie Teil 1: Zeitwende-1500. Akademie-Verlag, Berlin.

WELLS, C.E., HODGKINSON, D., HUCKERBY, E. 2000: Evidence for the possible role of beaver (Castor fiber) in the prehistoric ontogenesis of a mire in northwest England, UK. The Holocene 10, 503-508.

WENINGER, B., ALRAM-STERN, E., BAUER, E., CLARE, L., DANZEGLOCKE, U., JÖRIS, O., KUBATZKI, C., ROLLEFSON, G., TODOROVA, H., VAN ANDEL, T. 2006: Climate forcing due to the $8200 \mathrm{cal}$ yr BP event observed at Early Neolithic sites in the eastern Mediterranean. Quaternary Research 66, 401-420.

WICK, L., TINNER, L. 1997: Vegetation changes and timberline fluctuations in the Central Alps as indicators of Holocene climatic oscillations. Arctic Antarctic and Alpine Research 29, 445-458.

WILLERDING, U. 1986: Zur Geschichte der Unkräuter Mitteleuropas. Göttinger Schriften zur Vor- und Frühgeschichte 22. Wachholtz, Neumünster.

WILLERDING, U. 1992: Gärten und Pflanzen des Mittelalters. In: CarrollSpillecke, M. (Ed.): Der Garten von der Antike bis zum Mittelalter. Philipp von Zabern, Mainz, 249-284.

WILLERDING, U. 1996: Paläo-Ethnobotanik und Umweltgeschichte des Mittelalters. In: Bayerl, G., Fuchsloch, N., Meyer, T. (Eds.): Umweltgeschichte-Methoden, Themen, Potentiale. Waxmann, Münster, New York, München, Berlin, 41-65.

WILLERDING, U. 2003a: Grundlagen der landwirtschaftlichen Produktion. In: Benecke, N., Donat, P., Gringmuth-Dallmer, E., Willerding, U. (Eds.): Frühgeschichte der Landwirtschaft in Deutschland. Beiträge zur Ur- und Frühgeschichte Mitteleuropas 14, 3-33.

WILLERDING, U. 2003b: Die Landwirtschaft bei den Germanen und in den römischen Provinzen bis zur Völkerwanderungszeit. Ackerbau. In Benecke, N., Donat, P., Gringmuth-Dallmer, E., Willerding, U. (Eds.): Frühgeschichte der Landwirtschaft in Deutschland. Beiträge zur Ur- und Frühgeschichte Mitteleuropas 14, 35-57.

WINTERHALDER, B., KENNETT, D. 2006: Evolutionary biology and the transition to agriculture. University of California Press, Berkeley.

WIRTH, S. B., GLUR, L., GILLI, A., ANSELMETTI, F. S. 2013: Holocene flood frequency across the Central Alps - solar forcing and evidence for variations in North Atlantic atmospheric circulation. Quaternary Science Reviews 80, 112-128.
YANKO-HOMBACH, V., GILBERT, A. S., DOLUKHANOV, P. M. 2007: Controversy over the great flood hypothesis in the Black Sea in light of geological, paleontological, and archaeological evidence. Quaternary International 167/168, 91-113.

YURCO, F. J. 1999: "End of the Late Bronze Age and Other Crisis Periods: A Volcanic Cause". In: Teeter, E., Larson, J. A. (Eds.): Gold of Praise: Studies on Ancient Egypt in Honor of Edward F. Wente. Studies in Ancient Oriental Civilization 58. Oriental Institute of the University of Chicago, Chicago, 455-463.

ZEDER, M. A. 2005: A view from the Zagros: new perspectives on livestock domestication in the Fertile Crescent. In: Vigne, J.-D., Peters, J., Helmer, D. (Eds.): First steps of animal domestication. New archaeozoological approaches. Oxbow Books, Oxford, 125-146.

ZEDER, M. A. 2006: Central questions in the domestication of plants and animals. Evolutionary Anthropology 15, 105-117.

ZEDER, M. A. 2008: Domestication and early agriculture in the Mediterranean Basin: Origins, diffusion, and impact. Proceedings of the National Academy of Sciences 105, 11597-11604.

ZEHNDER, M., WELLER, F. 2006: Streuobstbau. Obstwiesen erleben und erhalten. Eugen Ulmer, Stuttgart.

ZIELINSKI, G. A. 2000: Use of paleo-records in determining variability within the volcanism-climate system. Quaternary Science Reviews 19, 417-438.

ZIELINSKI, G. A., MAYEWSKI, P. A., MEEKER, L. D., WHITLOW, S., TWICKLER, M. S., MORRISON, M., MEESE, D. A., GOW, A. J., ALLEY, R. B. 1994: Record of Volcanism Since 7000 B.C. from the GISP2 Greenland Ice Core and Implications for the Volcano-Climate System. Science 264, 948-952.

ZOHARY, D., HOPF, M., WEISS, E. 2012: Domestication of Plants in the Old World. The origin and spread of domesticated plants in southwest Asia, Europe, and the Mediterranean Basin. Fourth ed. Oxford University Press, New York.

ZOLITSCHKA, B., BEHRE, K.-E., SCHNEIDER, J. 2003: Human and climatic impact on the environment as derived from colluvial, fluvial and lacustrine archives - examples from the Bronze Age to the Migration period, Germany. Quaternary Science Reviews 22, 81-100.

ZOLLER, H. 1960: Pollenanalytische Untersuchungen zur Vegetationsgeschichte der insubrischen Schweiz. Denkschriften der Schweizerischen Naturforschenden Gesellschaft 83, Abh. 2, 45-156. 
